\title{
Crystal Structures, Local Atomic Environments, and Ion Diffusion Mechanisms of Scandium-Substituted Sodium Superionic Conductor (NASICON) Solid Electrolytes
}

\author{
Yue Deng, ${ }^{\dagger, \ddagger, \#, \|}$ Christopher Eames, ${ }^{\ddagger \odot}$ Long H. B. Nguyen, ${ }^{\S}$ Oliver Pecher, ${ }^{\S}$ Kent J. Griffith, ${ }^{\S}$
} Matthieu Courty, ${ }^{\dagger}$ Benoit Fleutot, ${ }^{\dagger, \#, \|}$ Jean-Noël Chotard, ${ }^{\dagger}, \# \odot$ Clare P. Grey, ${ }^{\S, \|_{\odot}}$ M. Saiful Islam, ${ }^{*},\left\|^{\ddagger},\right\|_{\odot}$ and Christian Masquelier*, ${ }^{\dagger}, \#, \|$ (1)

\footnotetext{
${ }^{\dagger}$ Laboratoire de Réactivité et de Chimie des Solides (UMR CNRS 7314), Université de Picardie Jules Verne, 33 rue Saint Leu, 80039 Cedex Amiens, France

${ }^{\ddagger}$ Department of Chemistry, University of Bath, Bath BA2 7AY, United Kingdom

"ALISTORE European Research Institute, FR CNRS 3104, 80039 Cedex Amiens, France

${ }^{\#}$ Réseau sur le Stockage Électrochimique de l'Énergie (RS2E), FR CNRS 3459, 80039 Amiens, France

${ }^{\S}$ Department of Chemistry, University of Cambridge, Cambridge CB2 1EW, United Kingdom
}

\section{Supporting Information}

\begin{abstract}
The importance of exploring new solid electrolytes for all-solid-state batteries has led to significant interest in NASICON-type materials. Here, the $\mathrm{Sc}^{3+}$-substituted NASICON compositions $\mathrm{Na}_{3} \mathrm{Sc}_{x} \mathrm{Zr}_{2-x}\left(\mathrm{SiO}_{4}\right)_{2-x}\left(\mathrm{PO}_{4}\right)_{1+x}$ (termed $\mathrm{N} 3)$ and $\mathrm{Na}_{2} \mathrm{Sc}_{y} \mathrm{Zr}_{2-y}\left(\mathrm{SiO}_{4}\right)_{1-y}\left(\mathrm{PO}_{4}\right)_{2+y}$ (termed N2) $(x, y=$ $0-1)$ are studied as model $\mathrm{Na}^{+}$-ion conducting electrolytes for solid-state batteries. The influence of $\mathrm{Sc}^{3+}$ substitution on the crystal structures and local atomic environments has been characterized by powder X-ray diffraction (XRD) and neutron powder diffraction (NPD), as well as solid-state ${ }^{23} \mathrm{Na},{ }^{31} \mathrm{P}$, and ${ }^{29} \mathrm{Si}$ nuclear magnetic resonance (NMR) spectroscopy. A
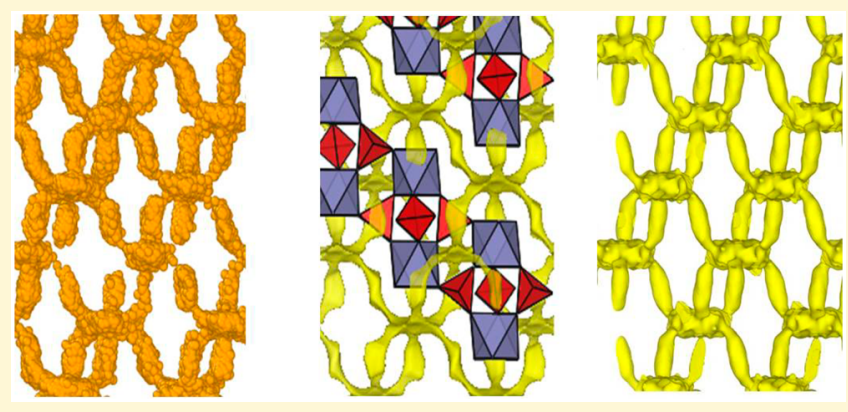
phase transition between 295 and $473 \mathrm{~K}$ from monoclinic $C 2 / c$ to rhombohedral $R \overline{3} c$ is observed for the N3 compositions, while $\mathrm{N} 2$ compositions crystallize in a rhombohedral $R \overline{3} c$ unit cell in this temperature range. Alternating current (AC) impedance spectroscopy, molecular dynamics (MD), and high temperature ${ }^{23} \mathrm{Na}$ NMR studies are in good agreement, showing that, with a higher $\mathrm{Sc}^{3+}$ concentration, the ionic conductivity (of about $10^{-4} \mathrm{~S} / \mathrm{cm}$ at $473 \mathrm{~K}$ ) decreases and the activation energy for ion diffusion increases. ${ }^{23} \mathrm{Na}$ NMR experiments indicate that the nature of the $\mathrm{Na}^{+}$-ion motion is two-dimensional on the local atomic scale of NMR although the long-range diffusion pathways are three-dimensional. In addition, a combination of MD, bond valence, maximum entropy/Rietveld, and van Hove correlation methods has been used to reveal that the $\mathrm{Na}^{+}$-ion diffusion in these NASICON materials is three-dimensional and that there is a continuous exchange of sodium ions between $\mathrm{Na}(1)$ and $\mathrm{Na}(2)$ sites.
\end{abstract}

\section{INTRODUCTION}

Rechargeable lithium ion batteries (LIBs) have come to dominate portable electronics over the past two decades, primarily due to their light weight and high energy density. ${ }^{1,2}$ However, there are concerns over the safety of LIBs and the abundance and cost of lithium. Sodium ion batteries (NIBs) are being actively investigated as an alternative, since sodium is more abundant and lower in cost while offering a similar intercalation chemistry to lithium. ${ }^{3-5}$ Nevertheless, safety issues related to flammable liquid electrolytes remain a serious concern. In contrast, all solid-state batteries (ASSBs), which use nonflammable ion-conducting solid electrolytes, have been considered as potential candidates for alternative energy storage devices. $^{6-8}$ One such family of candidate solid electrolytes is the NASICON (sodium (NA) SuperIonic CONductor) class of materials, which offer both high chemical stability and high $\mathrm{Na}^{+}$ mobility within a three-dimensional (3D) framework. ${ }^{9-17}$

NASICON-type crystal structures have been widely investigated and debated since the 1980s. ${ }^{9,10,18-24}$ The challenges associated with structure determination arise from two main factors: first, the difficulty in obtaining stoichiometric compositions due to possible sodium sublimation at high temperature and corresponding formation of $\mathrm{ZrO}_{2}$ during synthesis; ${ }^{25}$ second, the crystal structure varies according to the synthesis procedure and also to the thermal history of the sample. ${ }^{26,27}$ Three models are generally used to describe the

Received: December 19, 2017

Revised: $\quad$ March 23, 2018

Published: March 23, 2018 
possible crystal structures of NASICON materials: (1) $\alpha$ NASICON: $C 2 / c, a \approx 15.1 \AA, b \approx 8.7 \AA, c \approx 21.6 \AA$, and $\beta \approx$ $90.2^{\circ}$, which appears usually at low temperature close to 300 $\mathrm{K}^{12,28}(2) \beta$-NASICON: $C 2 / c, a \approx 15.1 \AA, b \approx 8.7 \AA, c \approx 8.8$ $\AA$, and $\beta \approx 124^{\circ}$, which crystallizes at intermediate temperature between 300 and $450 \mathrm{~K}^{29}$ and (3) $\gamma$-NASICON: $R \overline{3} c, a \approx 8.7$ $\AA$, and $c \approx 21.9 \AA$, which is the structure with the highest symmetry in the NASICON materials and can be obtained above $450 \mathrm{~K} .^{18,30}$

One interesting feature of the NASICON framework is the variety of accessible compositions within the general formula $\mathrm{Na}_{x} \mathrm{M}_{2}\left(\mathrm{SiO}_{4}\right)_{z}\left(\mathrm{PO}_{4}\right)_{3-z}{ }^{31,32}$ in which $x$ can vary between 0 and 4 and $\mathrm{M}$ can be di-, tri-, tetra-, and pentavalent transition metal cations. By substituting on the $M$ site, one can tune the electrochemical and ion conduction properties for specific applications. For example, in recent studies by Lalère et al. ${ }^{33}$ and by Noguchi et al., ${ }^{34}$ NASICON materials have been used simultaneously as both an electrode $\left(\mathrm{Na}_{3} \mathrm{~V}_{2}\left(\mathrm{PO}_{4}\right)_{3}\right)$ and an electrolyte $\left(\mathrm{Na}_{3} \mathrm{Zr}_{2}\left(\mathrm{SiO}_{4}\right)_{2}\left(\mathrm{PO}_{4}\right)\right)$, to form an all-solid-state battery that presents homogeneous interfaces between the electrodes and the electrolyte.

$\mathrm{Na}_{3} \mathrm{Zr}_{2}\left(\mathrm{SiO}_{4}\right)_{2}\left(\mathrm{PO}_{4}\right)$ is the first reported NASICON composition with a high ionic conductivity $(0.2 \mathrm{~S} / \mathrm{cm}$ at 573 $\mathrm{K})$. Among the different possible $\mathrm{M}^{3+}$ cations, scandium $\mathrm{Sc}^{3+}$ is the most similar to $\mathrm{Zr}^{4+}$ since both ions have empty $d$ orbitals and an essentially identical ionic radius. $\mathrm{Na}_{3} \mathrm{Sc}_{2}\left(\mathrm{PO}_{4}\right)_{3}$ has been reported to have a high ionic conductivity $\left(10^{-2} \mathrm{~S} / \mathrm{cm}\right.$ at 573 K). ${ }^{35}$ In addition, as recently reported by $\mathrm{Ma}$ et al., ${ }^{36} \mathrm{Sc}^{3+}$ containing NASICON compositions are promising electrolyte candidates since scandium is not redox active which results in a wide chemical stability window. ${ }^{37-41}$

In this work, we investigate the crystal structures and $\mathrm{Na}^{+}$ion transport properties of $\mathrm{Sc}^{3+}$-substituted NASICON materials $\mathrm{Na}_{3} \mathrm{Sc}_{x} \mathrm{Zr}_{2-x}\left(\mathrm{SiO}_{4}\right)_{2-x}\left(\mathrm{PO}_{4}\right)_{1+x}$ (referred to as $\mathrm{N} 3, x=0,0.25$, $0.50,0.75,1.0)$ and $\mathrm{Na}_{2} \mathrm{Sc}_{y} \mathrm{Zr}_{2-y}\left(\mathrm{SiO}_{4}\right)_{1-y}\left(\mathrm{PO}_{4}\right)_{2+y}$ (referred to as $\mathrm{N} 2, y=0,0.25,0.50,0.75,1.0)$ which are intermediate phases in the $\mathrm{NaZr}_{2}\left(\mathrm{PO}_{4}\right)_{3}-\mathrm{Na}_{4} \mathrm{Zr}_{2}\left(\mathrm{SiO}_{4}\right)_{3}-\mathrm{Na}_{3} \mathrm{Sc}_{2}\left(\mathrm{PO}_{4}\right)_{3}$ system (Figure 1). We synthesized these samples using solidstate methods and performed neutron powder diffraction (NPD) and synchrotron X-ray diffraction (SXRD) measurements to investigate their crystal structures. Solid-state ${ }^{23} \mathrm{Na}$,

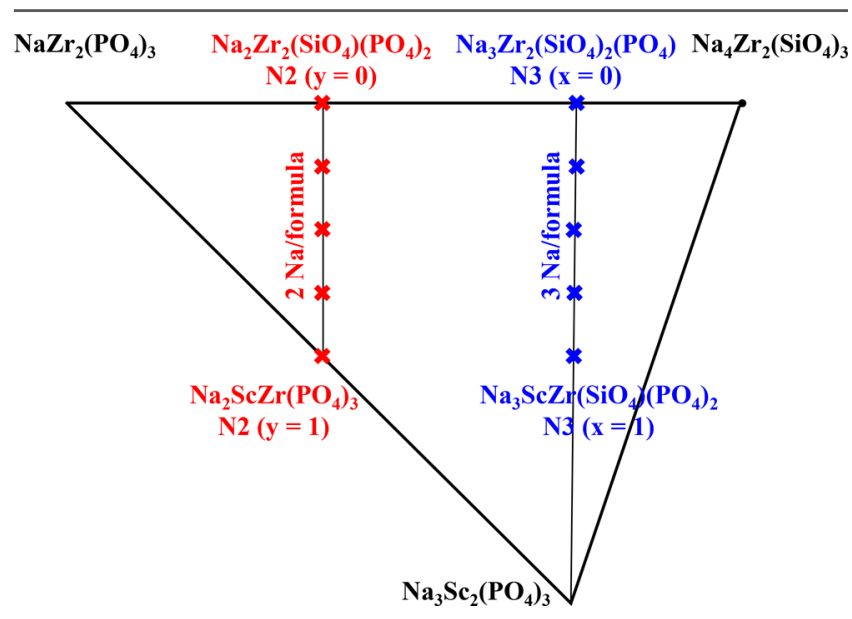

Figure 1. Relation between the end members $\mathrm{NaZr}_{2}\left(\mathrm{PO}_{4}\right)_{3}-$ $\mathrm{Na}_{4} \mathrm{Zr}_{2}\left(\mathrm{SiO}_{4}\right)_{3}-\mathrm{Na}_{3} \mathrm{Sc}_{2}\left(\mathrm{PO}_{4}\right)_{3}$ and the investigated samples of $\mathrm{Na}_{3} \mathrm{Sc}_{x} \mathrm{Zr}_{2-x}\left(\mathrm{SiO}_{4}\right)_{2-x}\left(\mathrm{PO}_{4}\right)_{1+x}(\mathrm{~N} 3$, blue $)$ and $\mathrm{Na}_{2} \mathrm{Sc}_{y} \mathrm{Zr}_{2-y}\left(\mathrm{SiO}_{4}\right)_{1-y^{-}}$ $\left(\mathrm{PO}_{4}\right)_{2+y}(\mathrm{~N} 2$, red).
${ }^{31} \mathrm{P}$, and ${ }^{29} \mathrm{Si}$ magic angle spinning (MAS) nuclear magnetic resonance (NMR) spectroscopy investigations together with ab initio magnetic calculations provide insights into both the local structure and $\mathrm{Na}^{+}$ion dynamics. The $\mathrm{Na}^{+}$ion transport properties are then investigated by combined experimental (NMR and alternating current (AC) impedance) and atomistic molecular dynamics (MD) techniques.

\section{METHODS}

Synthesis. $\mathrm{Na}_{2} \mathrm{CO}_{3}, \mathrm{Sc}_{2} \mathrm{O}_{3}, \mathrm{ZrOCl}_{2} \cdot 8 \mathrm{H}_{2} \mathrm{O}, \mathrm{SiO}_{2}$ (fumed, dried at $773 \mathrm{~K}$ for $3 \mathrm{~h}$ ), and $\mathrm{NH}_{4} \mathrm{H}_{2} \mathrm{PO}_{4}$ were used as raw materials for the synthesis of the target compositions. $\mathrm{Na}_{2} \mathrm{CO}_{3}, \mathrm{ZrOCl}_{2} \cdot 8 \mathrm{H}_{2} \mathrm{O}$, and $\mathrm{NH}_{4} \mathrm{H}_{2} \mathrm{PO}_{4}$ were first mixed in mortar and cold pressed into pellets. The pellets were heated at $443 \mathrm{~K}$ for $2 \mathrm{~h}$ and then at $673 \mathrm{~K}$ for $3 \mathrm{~h}$ to evaporate water and decompose $\mathrm{NH}_{4} \mathrm{H}_{2} \mathrm{PO}_{4}$. After cooling down to room temperature, the pellets were ground, mixed with $\mathrm{Sc}_{2} \mathrm{O}_{3}$ and $\mathrm{SiO}_{2}$, and finally ball milled (zirconia beads/powder $=3 / 1$ in mass ratio, $400 \mathrm{rpm}, 2 \mathrm{~h}$ ) to yield a homogeneous fine powder. The pristine mixture was cold pressed, fired at $1473 \mathrm{~K}$ for $12 \mathrm{~h}$, and pulverized after being cooled down to ambient temperature.

Diffraction. NPD patterns were collected using the high-resolution D1B diffractometer at Institute Laue-Langevin (Grenoble, France). High quality diffraction patterns were recorded between $2 \theta$ ranges of 0 to $130^{\circ}$, with a step size of $0.1^{\circ}$, accumulated over $2 \mathrm{~h}$. SXRD experiments at 295 and $473 \mathrm{~K}$ were performed at the 11BM beamline (APS, Argonne National Lab, U.S.A.) using a wavelength of 0.414209 A. Rietveld refinements of the crystal structure including lattice parameters, atomic positions, occupancies and atomic displacement parameters (ADPs), were performed using the Fullprof package. ${ }^{42}$ Using the "Bond_Str" interface in the same package, bond valence energy landscape calculations have been performed. In this method, the Rietveld refined structural model is used as input. The unit cell was then considered as a grid containing small units with size of $a / 10 \times b /$ $10 \times c / 10$. The energy of locating a $\mathrm{Na}^{+}$ion in each unit was calculated using the bond valence parameters. The bond valence energy landscape map was then obtained by setting an energy threshold (1 $\mathrm{eV}$ in our case). Furthermore, the Maximum Entropy Method $(\mathrm{MEM}) /$ Rietveld analysis was carried out using the RIETAN-FP software. ${ }^{43}$

Differential Scanning Calorimetry (DSC). DSC measurements were performed using a Netzsch DSC 204F1 apparatus operating at heating/cooling rates of $10 \mathrm{~K} \mathrm{~min}^{-1}$ between 238 and $623 \mathrm{~K}$. During the measurement, samples were heated from 298 to $623 \mathrm{~K}$, cooled down to $238 \mathrm{~K}$, heated to $623 \mathrm{~K}$, and then cooled back to $298 \mathrm{~K}$.

AC Impedance. The ionic conductivity was measured using pellet samples, which had been sintered in a FCT Spark Plasma Sintering apparatus at $100 \mathrm{~K} \mathrm{~min}^{-1}$ up to $973 \mathrm{~K}$ for 30 min under an applied pressure of $100 \mathrm{MPa}$ and under vacuum. The sintered pellets (of $90 \%$ compactness) were polished and then metalized on each face by gold sputtering using a Bal-Tec SCD 050. AC impedance measurements were performed under argon atmosphere to avoid any sample contact with oxygen and/or moisture at various stabilized temperatures ranging from 298 to $573 \mathrm{~K}$ (upon heating and cooling in steps of 25 $\mathrm{K})$ using a Bio-Logic MTZ-35 Impedance Analyzer. A frequency range of $30 \mathrm{MHz}$ to $0.1 \mathrm{~Hz}$ and an excitation voltage of $0.1 \mathrm{~V}$ were applied during the measurements. Using a Nyquist plot of the experimental data, the ionic conductivity $\sigma$ was then calculated using the eq 1 :

$$
\sigma=\frac{h}{R S}
$$

in which $h$ is the thickness of the solid electrolyte pellet, $S$ the pellet surface, and $R$ the total resistance obtained from the measurement.

Solid-State NMR Spectroscopy. Powder samples were packed into 2.5, 4.0, or $7.0 \mathrm{~mm} \mathrm{ZrO}_{2}$ rotors (Bruker) and closed with Kel-F or $\mathrm{BN}$ caps for ambient temperature (RT) and high temperature (HT) NMR experiments, respectively. HT (320 to $875 \mathrm{~K}$ ) ${ }^{23} \mathrm{Na}$ MAS NMR (4 kHz MAS frequency) measurements were performed at $9.4 \mathrm{~T}$ (Avance I console) using a Bruker double resonance $7.0 \mathrm{~mm}$ MAS 


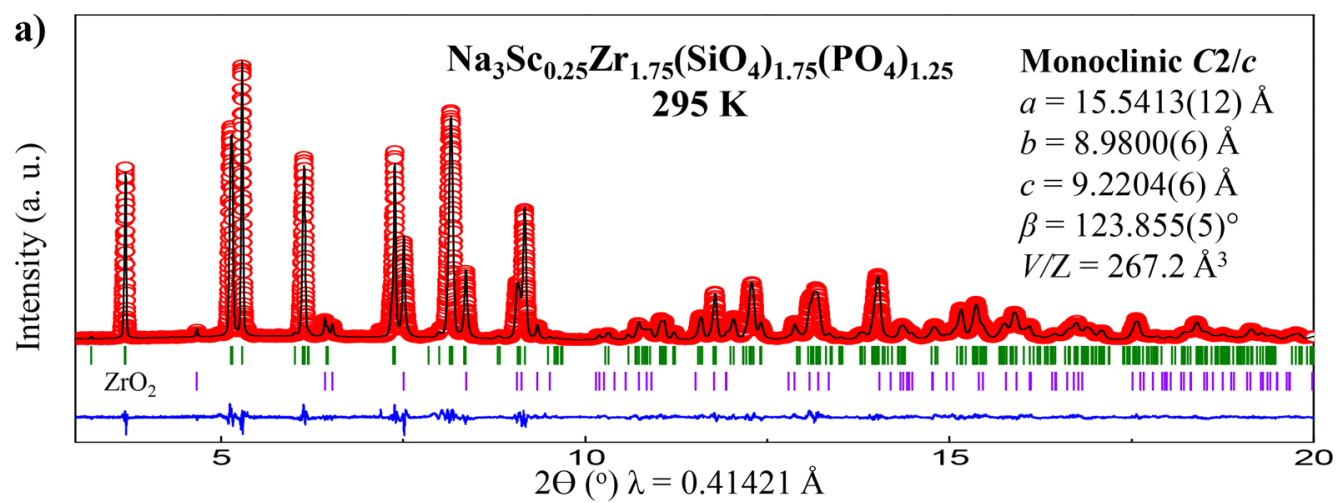

b)

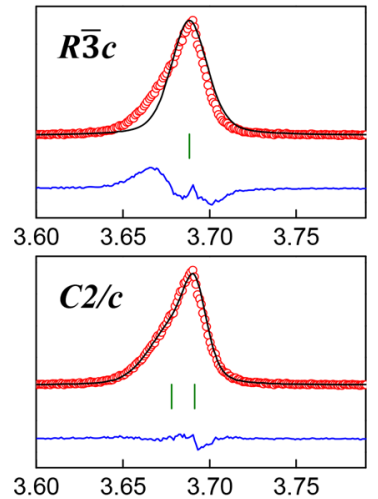

c)

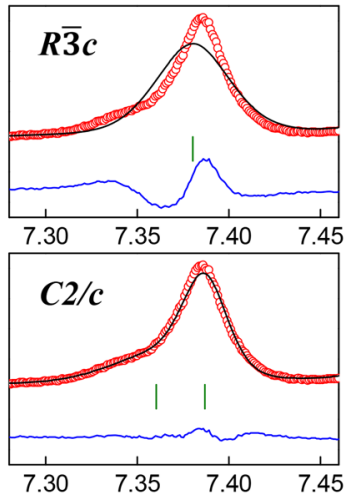

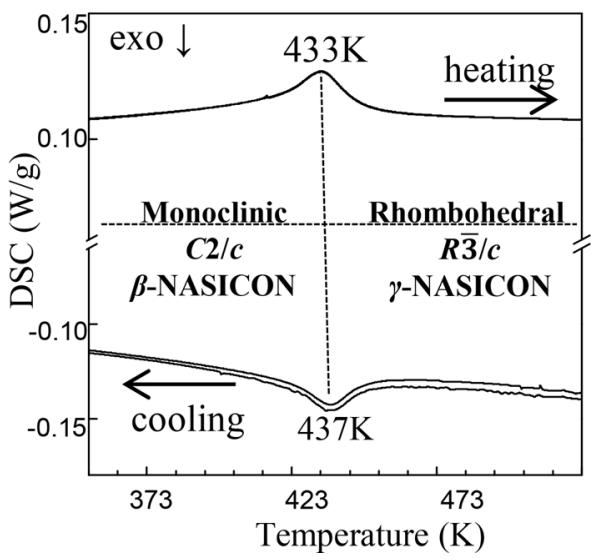

Figure 2. (a) Powder synchrotron $\mathrm{XRD}$ measurement at $295 \mathrm{~K}$ (red circles) and Rietveld refinement (black line) of $\mathrm{Na}_{3} \mathrm{Sc}_{0.25} \mathrm{Zr}_{1.75}\left(\mathrm{SiO}_{4}\right)_{1.75}\left(\mathrm{PO}_{4}\right)_{1.25}$. About 10 wt \% of $\mathrm{ZrO}_{2}$ was found. (b) Comparisons of refinements using $\gamma$ - and $\beta$-NASICON models. (c) DSC measurement of $\mathrm{Na}_{3} \mathrm{Zr}_{2}\left(\mathrm{SiO}_{4}\right)_{2}\left(\mathrm{PO}_{4}\right)$.

probe with laser heating of the sample. A temperature calibration using $\mathrm{KBr}$ was done prior to the measurements. ${ }^{23} \mathrm{Na} \mathrm{NMR}$ signal line shapes were determined by one-pulse experiments with high power pulses of $2.15 \mu \mathrm{s}$ and a repetition time of $0.1 \mathrm{~s}$. A saturation recovery pulse sequence was applied to determine ${ }^{23} \mathrm{Na}$ spin-lattice relaxation time constants $\left(T_{1}\right)$ at variable temperatures. The ${ }^{23} \mathrm{Na}$ NMR shifts were referenced to a $1 \mathrm{M} \mathrm{NaCl}$ solution in $\mathrm{D}_{2} \mathrm{O} .{ }^{44} \mathrm{RT}{ }^{31} \mathrm{P}$ MAS NMR (30 kHz MAS frequency) experiments were performed at $9.4 \mathrm{~T}$ using a Bruker $2.5 \mathrm{~mm}$ triple resonance MAS probe on an Avance I console. ${ }^{31} \mathrm{P}$ signals at $0.8 \mathrm{ppm}$ were referenced to ammonium dihydrogen phosphate. ${ }^{45}$ A one-pulse sequence with high power $0.75 \mu$ s pulses and a recycle delay of $1.0 \mathrm{~s}$ was applied to acquire the spectra. RT ${ }^{29} \mathrm{Si}$ MAS NMR (14 kHz MAS frequency) measurements were performed at $11.7 \mathrm{~T}$ (Avance III console) using a Bruker triple resonance $4.0 \mathrm{~mm}$ MAS probehead. Signal shifts have been referenced to trimethylsilylpropanoic acid at $0 \mathrm{ppm} .{ }^{46}$ The spectra were acquired by applying a one-pulse sequence with the pulse length of $1.30 \mu \mathrm{s}$ and a recycle delay of $60 \mathrm{~s}$. NMR data acquisition, processing, and raw data handling were done using the Bruker Topspin 3.2 package. Activation energies $\left(E_{\mathrm{a}}\right)$ were derived by fits of the temperature dependent ${ }^{23} \mathrm{Na} T_{1}$ values applying both a Bloembergen-Purcell-Pound (BPP, 3D diffusion) and a $2 \mathrm{D}$ diffusion model ${ }^{47-50}$ using in-house Mathematica scripts. Details on the BPP equation and 2D diffusion model are given in the Supporting Information.

Density Functional Theory (DFT) Calculations of NMR Tensors. Ab initio calculations of local structure and NMR tensors were performed with the CASTEP 8.0 plane wave DFT code. ${ }^{51}$ The electron exchange-correlation energy was treated with the PerdewBurke-Ernzerhof $(\mathrm{PBE})^{52}$ generalized gradient approximation (GGA) functional. Valence electrons were described with "on-the-fly" ultrasoft pseudopotentials ${ }^{53}$ and Koelling-Harmon scalar relativistic effects were included. Reconstruction of the all-electron wave function with the gauge-including projector augmented-wave (GIPAW) method ${ }^{54}$ was carried out to compute NMR tensors in the periodic systems. For all calculations, the Brillouin zone was sampled using a MonkhorstPack $^{55}$ grid with a $k$-point spacing of $0.05 \times 2 \pi \AA^{-1}$ and the maximum plane wave kinetic energy cutoff was $700 \mathrm{eV}$. Convergence was verified with respect to total energy $\left(1 \times 10^{-3} \mathrm{eV} \cdot\right.$ atom $\left.^{-1}\right),{ }^{31} \mathrm{P}$ magnetic shielding $( \pm 0.1 \mathrm{ppm})$, and ${ }^{29} \mathrm{Si}$ magnetic shielding $( \pm 0.05 \mathrm{ppm})$. Chemical shift $\left(\delta_{\text {iso }}\right)$ and calculated shielding $\left(\sigma_{\text {iso }}\right)$ are related via the linear expression:

$$
\delta_{\text {iso }}=m \sigma_{\text {iso }}+\sigma_{\text {ref }}
$$

In principle, if the slope of this line is assumed to be -1 , a single comparison between calculation and experiment of a known structure will yield the reference shielding. In practice, when possible, it is more reliable if multiple sites are compared between theory and experiment and linear regression employed to determine the slope and reference shielding. ${ }^{56}$ The latter strategy was employed in this work and the relations for both ${ }^{31} \mathrm{P}$ and ${ }^{29} \mathrm{Si}$ are taken from the literature; $\delta_{\text {iso }}\left({ }^{31} \mathrm{P}\right)=$ $-0.8618 \times \sigma_{\text {iso }}\left({ }^{31} \mathrm{P}\right)+237.7 \mathrm{ppm}$ from Diez-Gómez et al. ${ }^{57}$ and $\delta_{\text {iso }}\left({ }^{29} \mathrm{Si}\right)=-0.9958 \times \sigma_{\text {iso }}\left({ }^{29} \mathrm{Si}\right)+327.3 \mathrm{ppm}$ from a recent work by some of the authors. ${ }^{58}$ Starting structures were taken from the refined structural models using synchrotron data. The structures were geometry optimized using DFT forces until the change in energy, maximum atomic force, and maximum atomic displacement were less than $2 \times 10^{-5} \mathrm{eV} \cdot$ atom $^{-1}, 5 \times 10^{-2} \mathrm{eV} \cdot \AA^{-1}$, and $1 \times 10^{-3} \AA$, respectively.

Molecular Dynamics Simulations. Ion diffusion at finite temperature was modeled using interatomic potential based molecular dynamics (MD), which has been applied successfully to other battery materials. ${ }^{49,59-64}$ The parameters of the interatomic potentials were taken from the extensive library of potentials developed by Pedone et al. ${ }^{65}$ and the simulations were performed using the LAMMPS code. ${ }^{66}$ 
Prior to the MD simulations, these parameters have been used to perform energy minimization calculations. The simulated unit cell parameters and bond lengths are close to experimental values with a deviation less than $2 \%$. For each composition, based on the crystal structure determined from the diffraction techniques, a supercell containing about 8,000 atoms (1296 and $864 \mathrm{Na}^{+}$ions in N3 and N2 type compositions, respectively) was first energy minimized and then MD was applied for $15 \mathrm{~ns}$ with a time step of 0.002 ps. Several simulation runs at various temperatures $(373 \mathrm{~K}, 473 \mathrm{~K}, 573 \mathrm{~K}, 673 \mathrm{~K}$, $773 \mathrm{~K}$ ) were performed using the NPT ensemble. To monitor the diffusion, after the system had reached equilibrium, the mean squared displacement (MSD) of $\mathrm{Na}^{+}$ions was resolved as

$$
\mathrm{MSD}=\frac{1}{N} \sum_{i=1}^{N}\left[r_{i}(t)-r_{i}(0)\right]^{2}
$$

with $N$ equals the number of $\mathrm{Na}^{+}$ions in the simulation cell, $r_{i}(t)$ and $r_{i}(0)$ are the positions of $\mathrm{Na}^{+}$ion number $i$ at time $t$ and time 0 , respectively. The chemical diffusion coefficients $\left(D_{c}\right)$ were then calculated from the relation

$$
D_{\mathrm{c}}=\frac{1}{6} \frac{\mathrm{d}\langle\mathrm{MSD}\rangle}{\mathrm{d} t}
$$

The tracer diffusion coefficients $\left(D_{t}\right)$ were derived in a similar way using the mean squared displacement (MSD). The MSD plots for the sample $\mathrm{Na}_{3} \mathrm{Sc}_{0.25} \mathrm{Zr}_{1.75}\left(\mathrm{SiO}_{4}\right)_{1.75}\left(\mathrm{PO}_{4}\right)_{1.25}$ at various simulation temperatures are presented in the Supporting Information. The ionic conductivities were calculated according to the Nernst-Einstein equation:

$$
\frac{\sigma}{D_{c}}=\frac{n q^{2}}{f k T}
$$

in which $f$ is the correlation factor defined as the ratio of $D_{c}$ over $D_{t} n$ is the density of charge carrier (number of $\mathrm{Na}^{+}$ions per volume unit), $q$ the charge, $k$ the Boltzmann constant, and $T$ the system temperature. Calculations of Van Hove correlations ${ }^{67-68}$ were calculated and plotted according to the procedure given in Supporting Information.

\section{RESULTS AND DISCUSSION}

3.1. Crystal Structures and Local Atomic Environments. Diffraction. The crystal structures of $\mathrm{Na}_{3} \mathrm{Sc}_{x} \mathrm{Zr}_{2-x}\left(\mathrm{SiO}_{4}\right)_{2-x}\left(\mathrm{PO}_{4}\right)_{1+x}$ and $\mathrm{Na}_{2} \mathrm{Sc}_{y} \mathrm{Zr}_{2-y}\left(\mathrm{SiO}_{4}\right)_{1-y^{-}}$ $\left(\mathrm{PO}_{4}\right)_{2+y}(x, y=0,0.25,0.50,0.75$, and 1$)$ have been investigated first using diffraction techniques. For each composition, the synchrotron X-ray diffraction data have been collected at 295 and $473 \mathrm{~K}$. For N3 compositions $\left(\mathrm{Na}_{3} \mathrm{Sc}_{x} \mathrm{Zr}_{2-x}\left(\mathrm{SiO}_{4}\right)_{2-x}\left(\mathrm{PO}_{4}\right)_{1+x}\right)$ at $295 \mathrm{~K}$, the diffraction patterns can be indexed using the $\beta$-NASICON model $(\mathrm{C} 2 / c$, Supporting Information Table S1). To illustrate this, Figure 2, presents a typical synchrotron XRD pattern of $\mathrm{Na}_{3} \mathrm{Sc}_{0.25} \mathrm{Zr}_{1.75}\left(\mathrm{SiO}_{4}\right)_{1.75}\left(\mathrm{PO}_{4}\right)_{1.25}$ and the Rietveld refinement results. Notably, the pattern cannot be indexed in the higher symmetry $\gamma$-NASICON structure $(R \overline{3} c)$ at $295 \mathrm{~K}$. The reflection at around $2 \theta=3.69^{\circ}$ is asymmetric and a much more reliable fit is obtained if more than one Bragg reflection is used. The reflection at about $2 \theta=7.36^{\circ}$ is not present in the $\gamma$ model but can be fitted using the $\beta$ model.

At $473 \mathrm{~K}, \mathrm{~N} 3$ compositions can be indexed in the rhombohedral $\gamma$-NASICON model. A reversible thermal phenomenon can be detected in our DSC analysis at about $435 \mathrm{~K}$ (Figure 2), confirming the $\beta$ - to $\gamma$-phase transition. For $\mathrm{N} 2$ compositions $\left(\mathrm{Na}_{2} \mathrm{Sc}_{y} \mathrm{Zr}_{2-y}\left(\mathrm{SiO}_{4}\right)_{1-y}\left(\mathrm{PO}_{4}\right)_{2+y}\right)$ both the low temperature $(295 \mathrm{~K})$ and the high temperature $(473 \mathrm{~K})$ diffraction patterns can be indexed using the $\gamma$-NASICON model.
The Rietveld refined cell parameters for all the compositions investigated in this work are summarized in Figure 3 (the cell

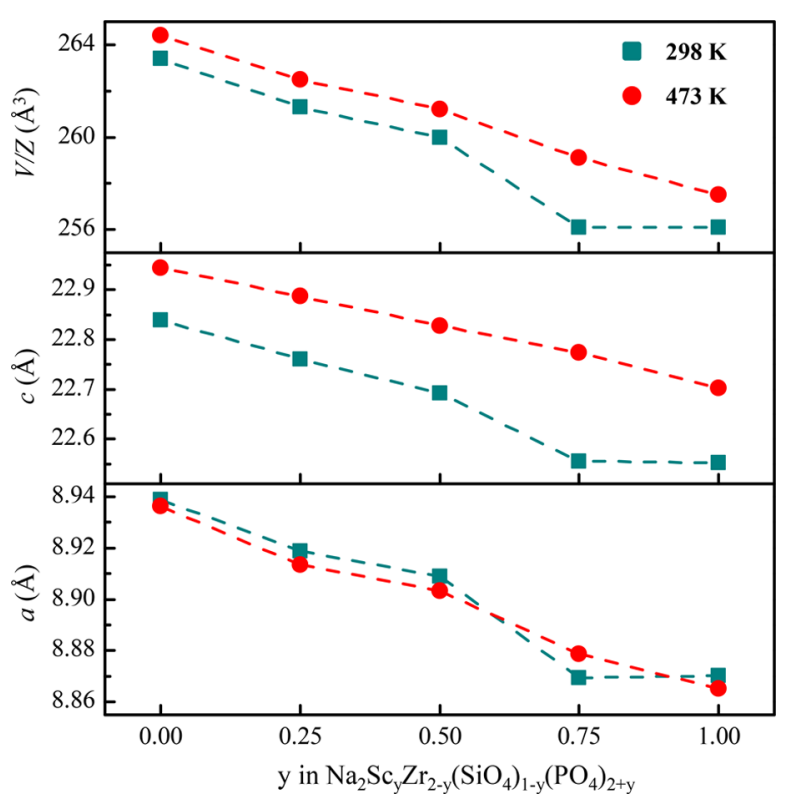

Figure 3. Evolution of the cell parameters as a function of $y$ in $\mathrm{Na}_{2} \mathrm{Sc}_{y} \mathrm{Zr}_{2-y}\left(\mathrm{SiO}_{4}\right)_{1-y}\left(\mathrm{PO}_{4}\right)_{2+y}$ at $298 \mathrm{~K}$ (dark cyan) and $473 \mathrm{~K}$ (red).

parameters, GoF, Rp, and Rwp values of the refinements are listed in Supporting Information Tables S1 and S2). When more $\mathrm{Zr}^{4+}$ is substituted by $\mathrm{Sc}^{3+}$ (higher $x$ values in $\mathrm{N} 3$ and $y$ values in N2), a decrease of cell parameters $a, b$, and $c$ can be observed, along with a decrease of the cell volume $V / Z$ as a result of smaller $\mathrm{ScO}_{6}\left(\right.$ vs $\left.\mathrm{ZrO}_{6}\right)$ and $\mathrm{PO}_{4}$ (vs $\mathrm{SiO}_{4}$ ) groups. This is in line with the average bond lengths of $\mathrm{Zr}-\mathrm{O}$ (2.099 $\AA), \mathrm{Sc}-\mathrm{O}(2.081 \AA), \mathrm{Si}-\mathrm{O}(1.556 \AA)$, and $\mathrm{P}-\mathrm{O}(1.528 \AA)$ found in $\mathrm{Na}_{3} \mathrm{Sc}_{2}\left(\mathrm{PO}_{4}\right)_{3}{ }^{69}$ and $\mathrm{Na}_{3} \mathrm{Zr}_{2}\left(\mathrm{SiO}_{4}\right)_{2}\left(\mathrm{PO}_{4}\right)^{9}$.

One interesting feature of the "NASICON type" compositions is their anisotropic thermal expansion of the unit cell. ${ }^{19}$ This can also be observed from the cell parameters listed in Figure 3. When the temperature is increased, minor contraction along the $a$ - and $b$-directions of the hexagonal cell is observed while the $c$-axis undergoes significant expansion. The net result is that the value of $V / Z$ does not change much with temperature. In the most significant case, a $1.2 \%$ increase is observed from 295 to $473 \mathrm{~K}$. Such a small volume expansion is an important criterion for all-solid-state batteries, since large changes in volume across the solid-solid interfaces can lead to delamination which breaks the sodium ion pathways.

In the NASICON crystal structure, $\mathrm{Sc}^{3+}$ and $\mathrm{Zr}^{4+}$ share the same crystallographic site and form $\mathrm{MO}_{6}$ octahedra, and $\mathrm{Si}^{4+}$ and $\mathrm{P}^{5+}$ share the same crystallographic site and form $\mathrm{XO}_{4}$ tetrahedra. Two $\mathrm{MO}_{6}$ octahedra are corner-connected to three $\mathrm{XO}_{4}$ tetrahedra, forming the well-known "lantern units" (Figure $4)$. In the $\beta$-NASICON crystal structure, three crystallographically different $\mathrm{Na}$ sites are present. In contrast, in the $\gamma$ NASICON phase, because of the symmetry there are only two types of $\mathrm{Na}$ sites, $\mathrm{Na}(1)$ and $\mathrm{Na}(2)$. In our refinement of the high temperature $(473 \mathrm{~K})$ structure, when the ADPs are refined anisotropically, the $\mathrm{Na}(1)$ site forms a flat disc in the $a b$-plane while $\mathrm{Na}(2)$ site forms a long ellipsoid along the $c$-direction. Their equivalent isotropic ADP values are listed in Figure 5 and in Supporting Information Table S3. As $x$ or $y$ increases, a 


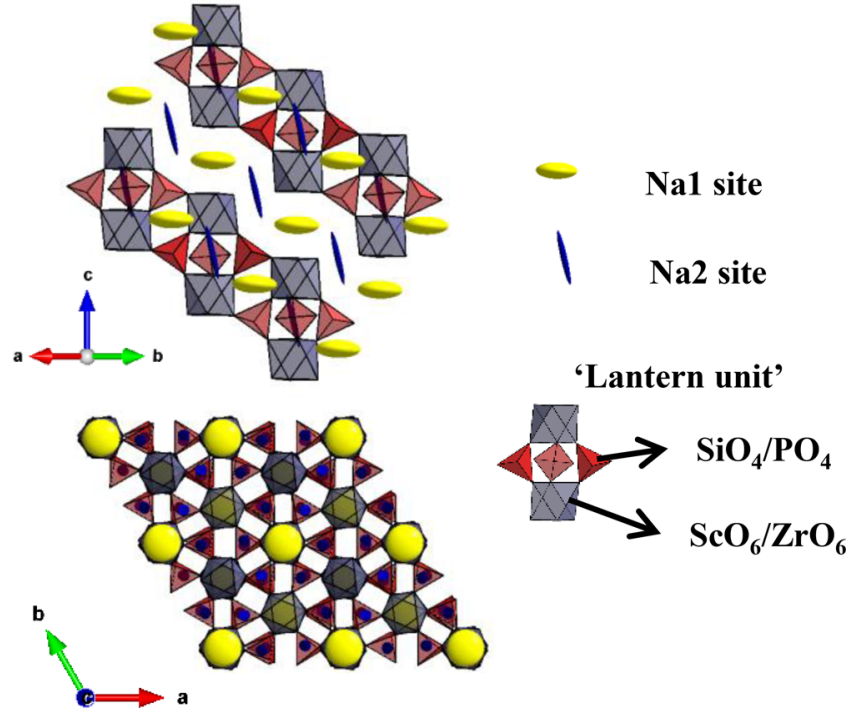

Figure 4. Schematic representations of the rhombohedral NASICON. Key: $\mathrm{ScO}_{6} / \mathrm{ZrO}_{6}$, gray octahedra; $\mathrm{SiO}_{4} / \mathrm{PO}_{4}$, red tetrahedra; $\mathrm{Na1}$, yellow discs; $\mathrm{Na} 2$, blue ellipsoids. $\mathrm{Na} 1$ and $\mathrm{Na} 2$ are shown as displacement ellipsoids with a probability value of $95 \%$.

decrease in the ADP values is observed, indicating that $\mathrm{Na}^{+}$ions are less mobile.

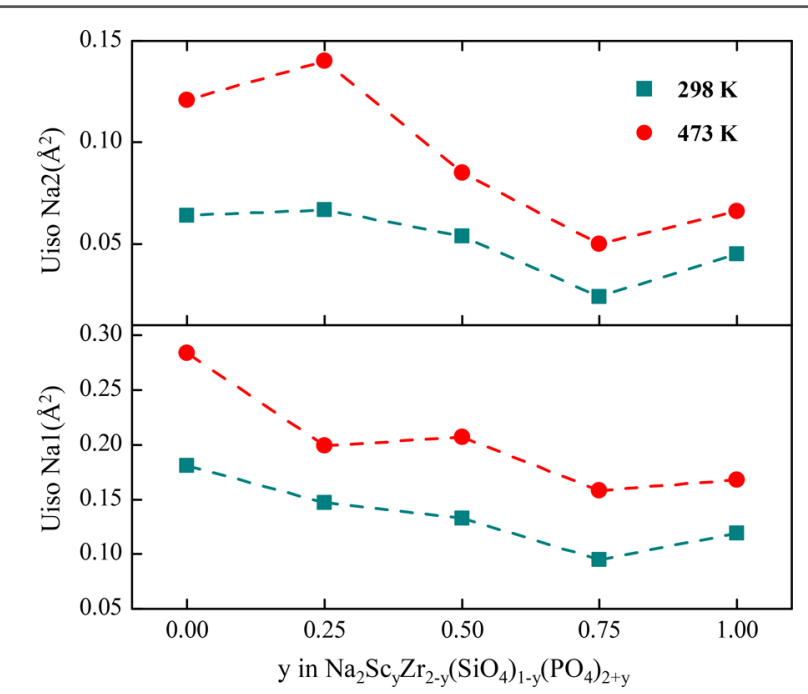

Figure 5. Equivalent isotropic ADPs Uiso for N2 $\left(\mathrm{Na}_{2} \mathrm{Sc}_{y} \mathrm{Zr}_{2-y}\left(\mathrm{SiO}_{4}\right)_{1-y}\left(\mathrm{PO}_{4}\right)_{2+y}\right)$. Values are obtained from Rietveld refinement of synchrotron XRD patterns.

${ }^{23} \mathrm{Na} N M R$. Room temperature (RT) ${ }^{23} \mathrm{Na}$ MAS NMR spectra show one symmetric signal at approximately $-28 \mathrm{ppm}$ with a number of rotational sidebands (RSBs) (Figure 6). The $\mathrm{Na}$ local environments are too chemically similar to be resolved at the applied MAS speed of $4 \mathrm{kHz}$ and under the moderate magnetic field strength of $9.4 \mathrm{~T}$. The residual line broadening coming at least in part from the second-order quadrupolar interaction is not completely removed by MAS. The ${ }^{23} \mathrm{Na}$ NMR signal line shape, shift, and full width at half-maximum (fwhm) change significantly with increasing temperature (Figure 7). When the temperature is increased above $374 \mathrm{~K}$, the RSBs are no longer observed. The fwhm reaches a maximum at $374 \mathrm{~K}$, dropping steadily thereafter until it reaches a plateau above 500 $\mathrm{K}$. The average chemical shift moves steadily to lower
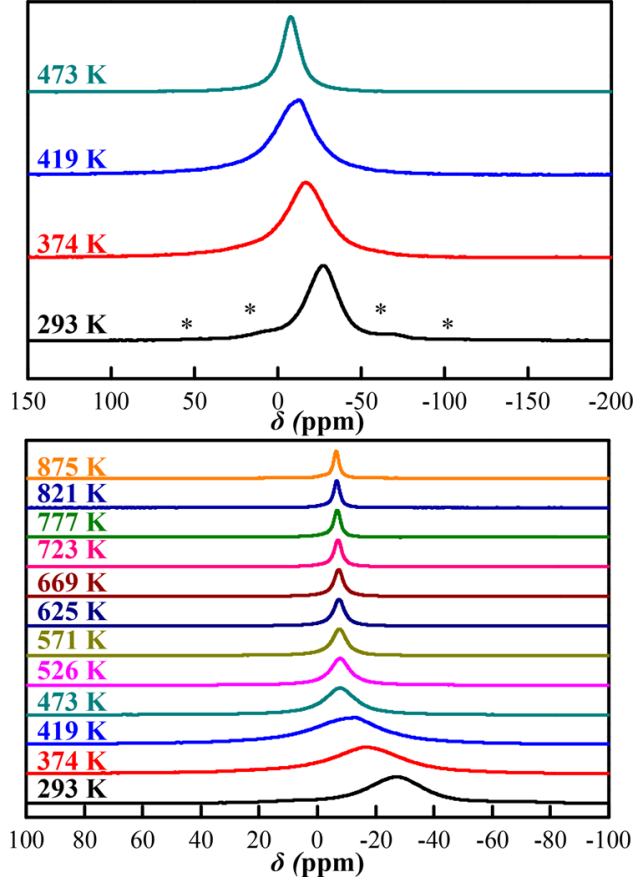

Figure 6. High temperature (HT) ${ }^{23} \mathrm{Na}$ MAS NMR signals (MAS frequency $4 \mathrm{kHz}, 9.4 \mathrm{~T})$ of $\mathrm{Na}_{3} \mathrm{Zr}_{2}\left(\mathrm{SiO}_{4}\right)_{2}\left(\mathrm{PO}_{4}\right)$. Rotational sidebands are marked with asterisks.
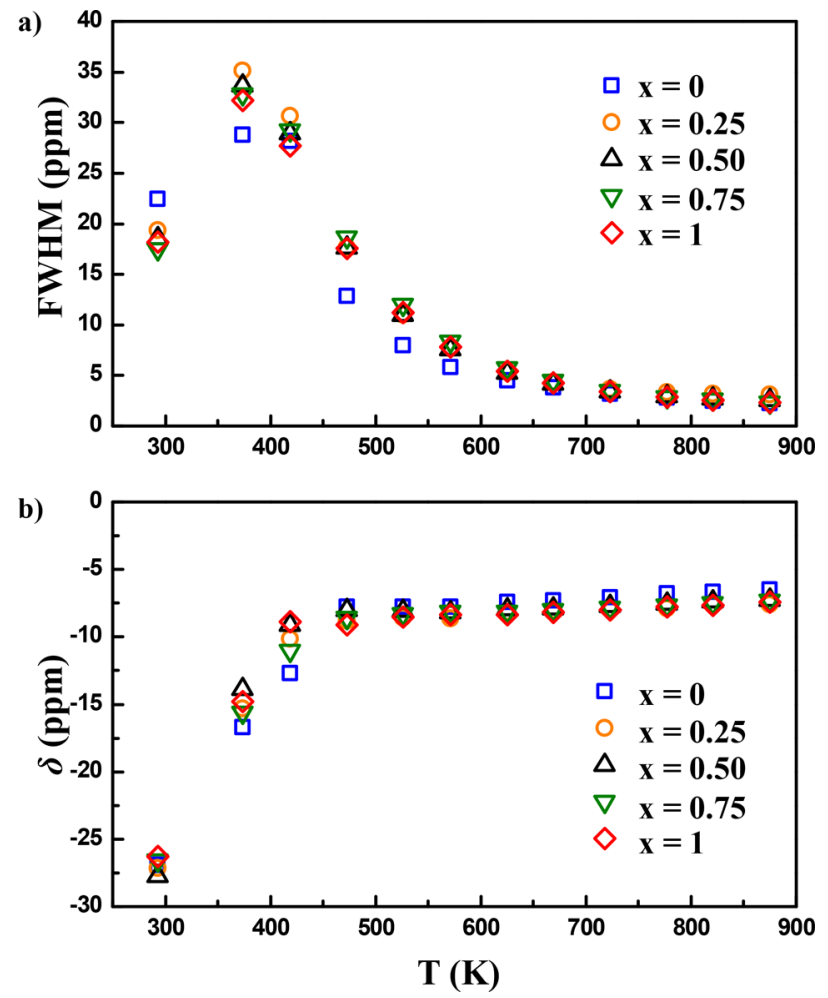

Figure 7. (a) fwhm and (b) shift of the ${ }^{23} \mathrm{Na}$ NMR signals of $\mathrm{Na}_{3} \mathrm{Sc}_{x} \mathrm{Zr}_{2-x}\left(\mathrm{SiO}_{4}\right)_{2-x}\left(\mathrm{PO}_{4}\right)_{1+x}$. Similar trends have also been found for $\mathrm{Na}_{2} \mathrm{Sc}_{y} \mathrm{Zr}_{2-y}\left(\mathrm{SiO}_{4}\right)_{1-y}\left(\mathrm{PO}_{4}\right)_{2+y}$.

frequencies until a temperature of $500 \mathrm{~K}$ is reached; thereafter the shift remains essentially constant.

The high temperature (HT) ${ }^{23} \mathrm{Na}$ NMR line shape development indicates a strong influence of the temperature on the $\mathrm{Na}^{+}$ion diffusion. The increase of fwhm between RT 
a) $\mathrm{Na}_{2} \mathrm{Sc}_{\mathrm{y}} \mathrm{Zr}_{2-\mathrm{y}}\left(\mathrm{SiO}_{4}\right)_{1-\mathrm{y}}\left(\mathrm{PO}_{4}\right)_{2+\mathrm{y}}$

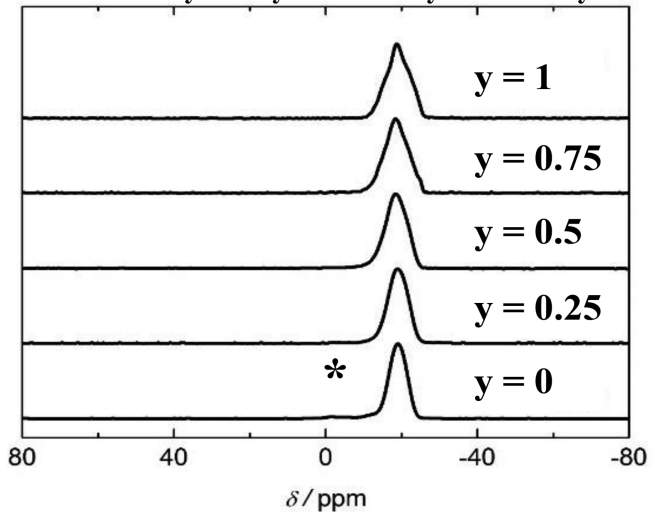

b) $\quad \mathrm{Na}_{3} \mathrm{Sc}_{\mathrm{x}} \mathrm{Zr}_{2-\mathrm{x}}\left(\mathrm{SiO}_{4}\right)_{2-\mathrm{x}}\left(\mathrm{PO}_{4}\right)_{1+\mathrm{x}}$

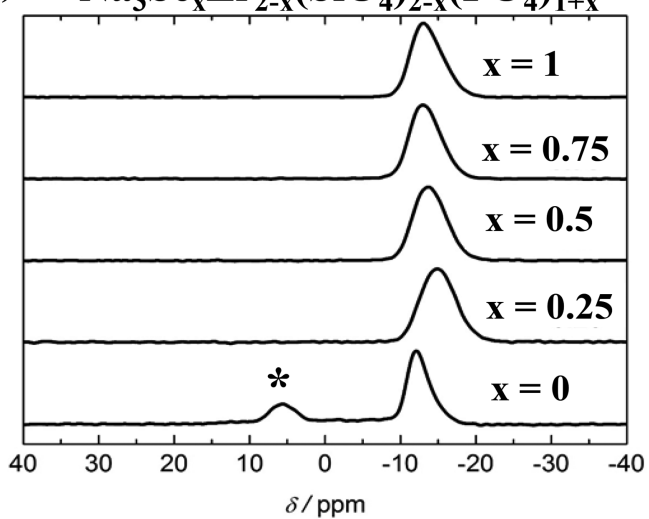

Figure 8. Room temperature (RT) ${ }^{31} \mathrm{P}$ MAS NMR signals (MAS frequency $\left.30 \mathrm{kHz}, 9.4 \mathrm{~T}\right)$ of $^{N_{2}} \mathrm{Sc}_{y} \mathrm{Zr}_{2-y}\left(\mathrm{SiO}_{4}\right)_{1-y}\left(\mathrm{PO}_{4}\right)_{2+y}(\mathrm{a})$ and $\mathrm{Na}_{3} \mathrm{Sc}_{x} \mathrm{Zr}_{2-x}\left(\mathrm{SiO}_{4}\right)_{2-x}\left(\mathrm{PO}_{4}\right)_{1+x}(\mathrm{~b})$.

and $374 \mathrm{~K}$ is ascribed to either a change in the $\mathrm{Na}$ local environments of sites occupied by $\mathrm{Na}$ with increasing temperature or to an interference between motion and magic angle spinning motion on the MAS time scale. This prevents the method from removing sources of line broadening such as the quadrupolar interaction and dipolar coupling. ${ }^{70}$ The steady decrease in fwhm above $374 \mathrm{~K}$ indicates increased motion. The narrowing limit (or fast regime) is reached above $500 \mathrm{~K}$ where ionic motion is occurring on a time scale that effectively averages any shift distribution, dipolar coupling, and quadrupolar coupling interactions, i.e., the hops between different $\mathrm{Na}^{+}$sites are expected to occur with frequencies in the $\mathrm{kHz}$ regime or above, on the basis of typical values for these interactions.

${ }^{31} \mathrm{P} N \mathrm{~N}$. Room temperature ${ }^{31} \mathrm{P}$ MAS NMR reveals two signals for $\mathrm{Na}_{2} \mathrm{Zr}_{2}\left(\mathrm{SiO}_{4}\right)\left(\mathrm{PO}_{4}\right)_{2}$ and $\mathrm{Na}_{3} \mathrm{Zr}_{2}\left(\mathrm{SiO}_{4}\right)_{2}\left(\mathrm{PO}_{4}\right)$ (Figure 8) of which the minor intensity resonance peaks are due to the formation of a zirconium-deficient impurity phase that has been reported previously. ${ }^{71}$

Only one asymmetric ${ }^{31} \mathrm{P}$ signal is present for all other compositions (Figure 8). One might expect the asymmetry of these signals to be caused by the random distribution of $\mathrm{Zr} / \mathrm{Sc}$ on the second coordination spheres with respect to the $\mathrm{P}$ site, as recently shown in the NASICON structure $\mathrm{Li}(\mathrm{Ti}$ / $\mathrm{Ge})_{2}\left(\mathrm{PO}_{4}\right)_{3}$ solid solution. ${ }^{57}$ This $\mathrm{Zr} / \mathrm{Sc}$ disorder leads to various local chemical environments: $\mathrm{P}(\mathrm{OZr})_{4}, \mathrm{P}(\mathrm{OZr})_{3}(\mathrm{OSc})$, $\mathrm{P}(\mathrm{OZr})_{2}(\mathrm{OSc})_{2}, \mathrm{P}(\mathrm{OZr})(\mathrm{OSc})_{3}$, and $\mathrm{P}(\mathrm{OSc})_{4} . \mathrm{Ab}$ initio calculations were undertaken to understand the local structure and NMR results, which revealed that the ${ }^{31} \mathrm{P}$ chemical shift is more strongly affected by the next-nearest neighbor (NNN) sodium occupancy than the NNN metal distribution (Supporting Information Figure S4). Several spectral features may be understood in this context. First, the fwhm of the ${ }^{31} \mathrm{P}$ NMR resonances of $\mathrm{Zr}$ end-members $(x, y=0.00)$ $\mathrm{Na}_{2} \mathrm{Zr}_{2}\left(\mathrm{SiO}_{4}\right)\left(\mathrm{PO}_{4}\right)_{2}$ and $\mathrm{Na}_{3} \mathrm{Zr}_{2}\left(\mathrm{SiO}_{4}\right)_{2}\left(\mathrm{PO}_{4}\right)$ were 5.5 and $3.5 \mathrm{ppm}$, respectively, significantly larger than the fwhm of $\leq$ 0.5 ppm observed for $\operatorname{LiTi}_{2}\left(\mathrm{PO}_{4}\right)_{3}$ and $\mathrm{LiGe}_{2}\left(\mathrm{PO}_{4}\right)_{3}$ in the fully lithium-ordered NASICON phases in prior studies. ${ }^{57,72}$ Furthermore, these ${ }^{31} \mathrm{P}$ resonances are asymmetric and contain shoulders, which cannot be explained by $\mathrm{Zr} / \mathrm{Sc}$ disorder since $\mathrm{Sc}$ is not present at $x, y=0$ but can be rationalized by the $\mathrm{Na}$ disorder. The ab initio NMR calculations from relaxed structures yielded a range of ${ }^{31} \mathrm{P}$ shifts from -11 to $-25 \mathrm{ppm}$ in $\mathrm{Na}_{2} \mathrm{Sc}_{y} \mathrm{Zr}_{2-y}\left(\mathrm{SiO}_{4}\right)_{1-y}\left(\mathrm{PO}_{4}\right)_{2+y}$ and -7 to $-19 \mathrm{ppm}$ for $\mathrm{Na}_{3} \mathrm{Sc}_{x} \mathrm{Zr}_{2-x}\left(\mathrm{SiO}_{4}\right)_{2-x}\left(\mathrm{PO}_{4}\right)_{1+x}$, in excellent agreement with experimental results. The slight positive shift from $\mathrm{N} 2$ to $\mathrm{N} 3$ is also explained by the average increase in $\mathrm{Na} \mathrm{NNN}$ coordination in N3; approximately, for both series, each sodium NNN (defined by a $4.5 \AA$ radius) shifts the ${ }^{31} \mathrm{P}$ resonance by approximately +4 ppm.

${ }^{29}$ Si NMR. Room temperature ${ }^{29}$ Si MAS NMR reveals two signals at -94 and $-111 \mathrm{ppm}$ (Supporting Information Figure $\mathrm{S} 5$ ). The resonance at $-111 \mathrm{ppm}$ is due to $\mathrm{SiO}_{2}$ impurity, which could not be detected in the diffraction experiments due to its amorphous nature. The $-94 \mathrm{ppm}$ signal intensity continuously decreases with higher $x$ values for $\mathrm{Na}_{3} \mathrm{Sc}_{x} \mathrm{Zr}_{2-\mathrm{x}}\left(\mathrm{SiO}_{4}\right)_{2-\mathrm{x}}\left(\mathrm{PO}_{4}\right)_{1+x}$ and $y$ values for $\mathrm{Na}_{2} \mathrm{Sc}_{y} \mathrm{Zr}_{2-\mathrm{y}}\left(\mathrm{SiO}_{4}\right)_{1-\mathrm{y}}\left(\mathrm{PO}_{4}\right)_{2+y}$, respectively, which is in agreement with the substitution of the $\mathrm{SiO}_{4} / \mathrm{PO}_{4}$ units. $\mathrm{Ab}$ initio magnetic shielding calculations suggest a range of -93 to -101 ppm in $\mathrm{Na}_{2} \mathrm{Sc}_{y} \mathrm{Zr}_{2-\mathrm{y}}\left(\mathrm{SiO}_{4}\right)_{1-\mathrm{y}}\left(\mathrm{PO}_{4}\right)_{2+y}$ and -85 to $-97 \mathrm{ppm}$ for $\mathrm{Na}_{3} \mathrm{Sc}_{x} \mathrm{Zr}_{2-\mathrm{x}}\left(\mathrm{SiO}_{4}\right)_{2-\mathrm{x}}\left(\mathrm{PO}_{4}\right)_{1+x}$ for the ${ }^{29} \mathrm{Si} \mathrm{NMR}$ spectra, which supports the experimental assignment and observed range. These calculations confirm a silicon shift dependence analogous to that of phosphorus; each sodium NNN results in a shift of the ${ }^{29} \mathrm{Si}$ resonance by approximately $+4 \mathrm{ppm}$. Thus, unlike the lithium-ordered $\mathrm{Li}(\mathrm{Ti} / \mathrm{Ge})_{2}\left(\mathrm{PO}_{4}\right)_{3}$ solid solution, ${ }^{57}$ the cation distribution may be a contributing factor to the chemical shift; however, it is relatively modest in our samples and cannot be distinguished in the sodium disorder-dominated NMR spectra.

3.2. $\mathrm{Na}^{+}$Ion Conductivity. $\mathrm{Na}^{+}$diffusion rates and conductivities are important properties for the effective operation of a solid state battery, which we investigate here using AC impedance, MD simulations, and ${ }^{23} \mathrm{Na} \mathrm{NMR}$ spinlattice relaxation time measurements. The ionic conductivity has been measured using $\mathrm{AC}$ impedance for three different compositions: $\mathrm{Na}_{3} \mathrm{Sc}_{0.25} \mathrm{Zr}_{1.75}\left(\mathrm{SiO}_{4}\right)_{1.75}\left(\mathrm{PO}_{4}\right)_{1.25}, \mathrm{Na}_{2} \mathrm{Zr}_{2}\left(\mathrm{SiO}_{4}\right)$ $\left(\mathrm{PO}_{4}\right)_{2}$, and $\mathrm{Na}_{2} \mathrm{ScZr}\left(\mathrm{PO}_{4}\right)_{3}$. Figure 9 shows typical Nyquist plots obtained for $\mathrm{Na}_{3} \mathrm{Sc}_{0.25} \mathrm{Zr}_{1.75}\left(\mathrm{SiO}_{4}\right)_{1.75}\left(\mathrm{PO}_{4}\right)_{1.25}$ at various temperatures. An elongated semicircle is observed at high frequencies of less than $1 \mathrm{kHz}$, which can be attributed to Naion conduction, and an oblique line at lower frequency due to the ionic blocking (gold) electrode. The spectra were fitted using the equivalent circuit inserted in Figure 9a.

At low temperatures and high frequencies, the contribution from the bulk of the material and the grain boundary can be separated (corresponding to R2//CPE2 and R3//CPE3, respectively). This separation can be observed up to $373 \mathrm{~K}$. A fast reduction of the semicircle diameter is noticed upon heating, revealing the enhancement of the ionic conductivity 
a)

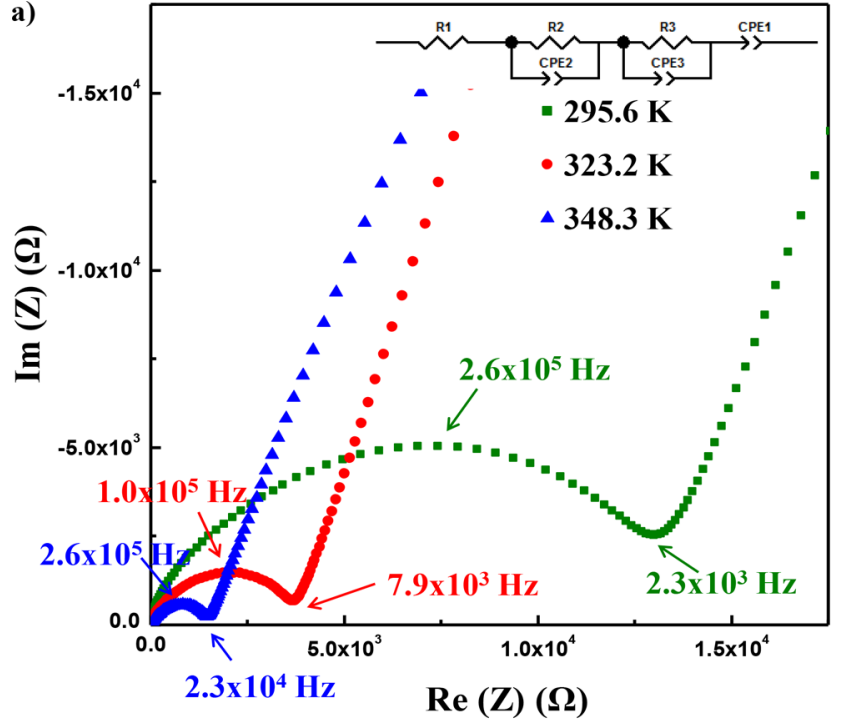

b)

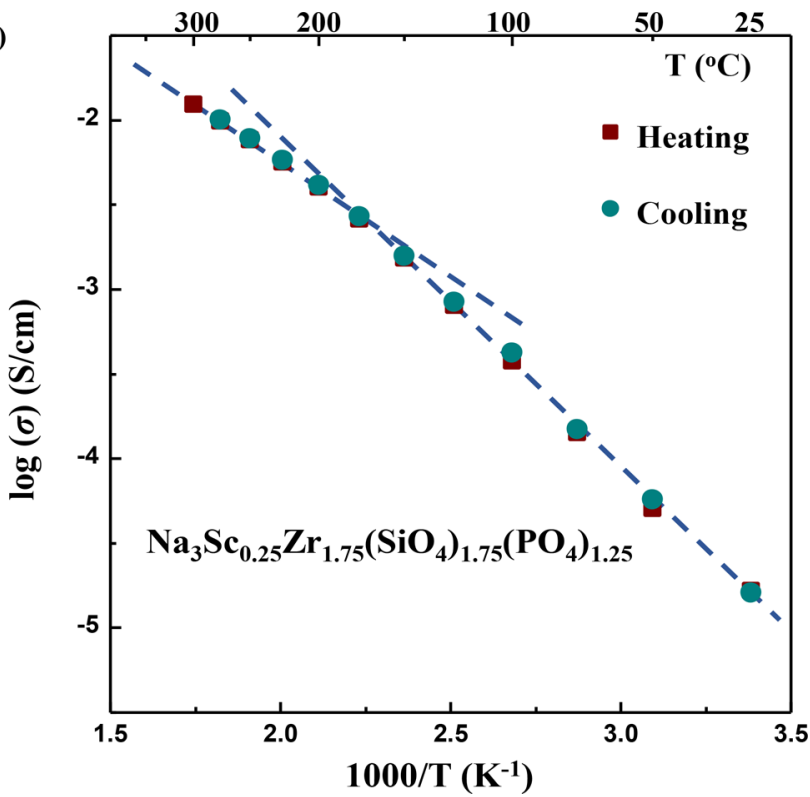

Figure 9. (a) Nyquist plots of $\mathrm{AC}$ impedance measured data. The plots are obtained by measuring a $\mathrm{Na}_{3} \mathrm{Sc}_{0.25} \mathrm{Zr}_{1.75}\left(\mathrm{SiO}_{4}\right)_{1.75}\left(\mathrm{PO}_{4}\right)_{1.25}$ pellet $\left(h=1.17 \mathrm{~mm}\right.$ and $\left.S=66.05 \mathrm{~mm}^{2}\right)$ at $295.6,323.2$, and $348.2 \mathrm{~K}$. The equivalent circuit used for data fitting is inserted. $\mathrm{R} 1$ stands for the systematic resistance coming from the apparatus. (b) AC impedance measured conductivity values of $\mathrm{Na}_{3} \mathrm{Sc}_{0.25} \mathrm{Zr}_{1.75}\left(\mathrm{SiO}_{4}\right)_{1.75}\left(\mathrm{PO}_{4}\right)_{1.25}$ upon heating and cooling.

with temperature. The measured capacitance gives values of between $10^{-10}$ and $10^{-9} \mathrm{~F}$, in agreement with the value suggested by Irvine et al. $^{73}$

The evolution of the ionic conductivity at various temperatures is plotted in Figure $9 \mathrm{~b}$ (sum of bulk and grain boundaries contributions) for $\mathrm{Na}_{3} \mathrm{Sc}_{0.25} \mathrm{Zr}_{1.75}\left(\mathrm{SiO}_{4}\right)_{1.75}\left(\mathrm{PO}_{4}\right)_{1.25}$. We note the superposition of ionic conductivity values between heating and cooling steps, consistent with a process that is reversible with temperature, and that there are no additional detrimental reactions during the measurements.

From these conductivity values, activation energies for $\mathrm{Na}^{+}-$ ion diffusion can be obtained using an Arrhenius plot $(\log (\sigma T)$ vs $1 / T)$, which is shown in Figure 10. An inflection point can be observed in the Arrhenius plot around $448 \mathrm{~K}$ for

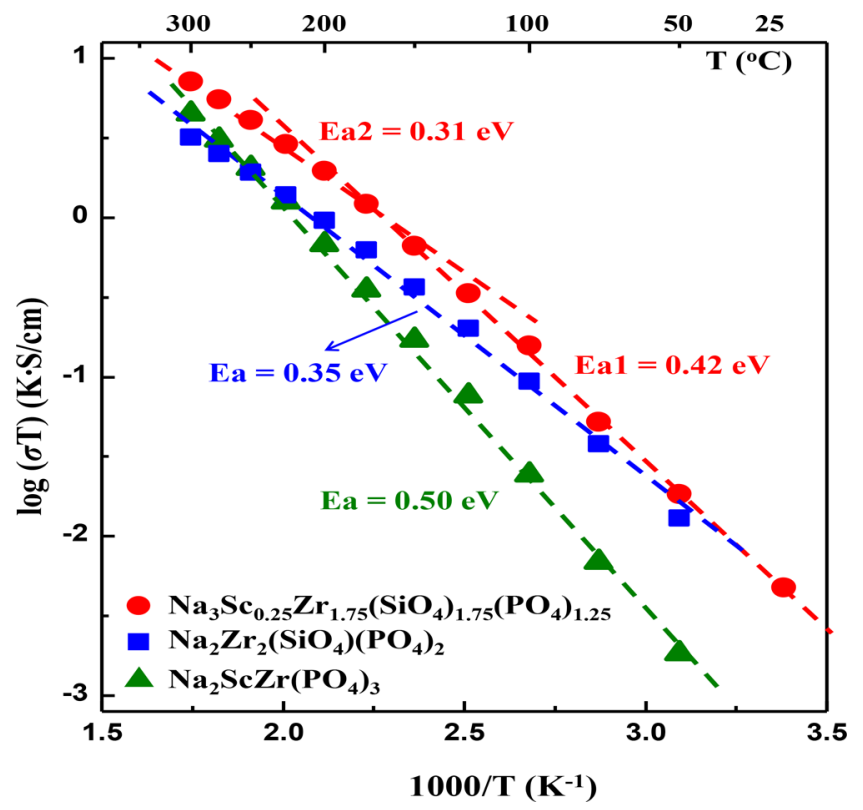

Figure 10. Arrhenius plot from $A C$ impedance measurements for $\mathrm{Na}_{3} \mathrm{Sc}_{0.25} \mathrm{Zr}_{1.75}\left(\mathrm{SiO}_{4}\right)_{1.75}\left(\mathrm{PO}_{4}\right)_{1.25}$ (red), $\mathrm{Na}_{2} \mathrm{Zr}_{2}\left(\mathrm{SiO}_{4}\right)\left(\mathrm{PO}_{4}\right)_{2}$ (blue), and $\mathrm{Na}_{2} \mathrm{ScZr}\left(\mathrm{PO}_{4}\right)_{3}$ (green).

$\mathrm{Na}_{3} \mathrm{Sc}_{0.25} \mathrm{Zr}_{1.75}\left(\mathrm{SiO}_{4}\right)_{1.75}\left(\mathrm{PO}_{4}\right)_{1.25}$ (Figure 10, red), indicating a modification of the activation energy. This can be linked to the phase transition from monoclinic $C 2 / c$ to rhombohedral $R \overline{3} c$, previously observed for this type of compound in which the phase transition induces a modification of ionic transport properties. No inflection point in the Arrhenius plot is observed for N2 compounds (Figure 10, blue and green), which is in agreement with the results from diffraction. For N2 compounds, the addition of $\mathrm{Sc}^{3+}$ increases the activation energy from 0.35 to $0.50 \mathrm{eV}$ and decreases the ionic conductivity. The influence of $\mathrm{Sc}^{3+}$-substitution on the ionic conductivity is further revealed by the $\mathrm{MD}$ simulated ionic conductivities at $473 \mathrm{~K}$, summarized in Table 1.

Table 1. Calculated $\mathrm{Na}^{+}$-Ion Conductivities at $473 \mathrm{~K}$ for $\mathrm{N} 3$ $\left(\mathrm{Na}_{3} \mathrm{Sc}_{x} \mathrm{Zr}_{2-x}\left(\mathrm{SiO}_{4}\right)_{2-x}\left(\mathrm{PO}_{4}\right)_{1+x}\right)$ and $\mathrm{N} 2$

$\left(\mathrm{Na}_{2} \mathrm{Sc}_{y} \mathrm{Zr}_{2-y}\left(\mathrm{SiO}_{4}\right)_{1-y}\left(\mathrm{PO}_{4}\right)_{2+y}\right)$ from MD Simulations

\begin{tabular}{cccccc}
\multicolumn{7}{c}{$\sigma$ at $473 \mathrm{~K}(\mathrm{mS} / \mathrm{cm})$} \\
& & \multicolumn{5}{c}{ or $y$} & \\
\cline { 3 - 6 } $\mathrm{N} 3$ & 0 & 0.25 & 0.50 & 0.75 & 1 \\
$\mathrm{~N} 2$ & 1.40 & 0.89 & 0.41 & 0.29 & 0.13 \\
& 0.67 & 0.29 & 0.20 & 0.13 & 0.15 \\
\hline
\end{tabular}

From these ionic conductivity values, two key features appear. First, with the same $\mathrm{Sc}^{3+}$ content per formula unit $(x=$ $y$ ), N3 has a higher ionic conductivity than N2 (except for the case of $x=y=1$, where the two conductivity values are very close to each other); this result is probably due to the increased number of ionic charge carriers in the N3 system. Second, the ionic conductivity decreases as more $\mathrm{Sc}^{3+}$ is substituted on the $\mathrm{Zr}^{4+}$ site, in agreement with the AC impedance measurements. The maximum conductivity is achieved in the composition $\mathrm{Na}_{3} \mathrm{Zr}_{2}\left(\mathrm{SiO}_{4}\right)_{2}\left(\mathrm{PO}_{4}\right)(\mathrm{N} 3 x=0$, with a $\mathrm{Si} / \mathrm{P}$ ratio of $2 / 1)$. The trend is in line with that of the isotropic ADP values discussed in section 3.1. With a higher $x$ or $y$ value there are two key features: (1) the decrease of the lattice parameters leads to a 
more compact unit cell, leaving less free volume for sodium-ion diffusion; (2) the crystal structure is more disordered due to the random distribution of $\mathrm{Sc} / \mathrm{Zr}$ on $\mathrm{M}\left(\mathrm{O}_{6}\right)$ sites and of $\mathrm{Si} / \mathrm{P}$ on $\mathrm{X}\left(\mathrm{O}_{4}\right)$ sites. This suggests that the crystal structural disorder impedes sodium-ion diffusivity. Roy et al. ${ }^{61,74}$ have shown in their $\mathrm{MD}$ simulations that the ordering of $\mathrm{XO}_{4}$ groups significantly influences the $\mathrm{Na}^{+}$conductivity: depending on the distribution of $\mathrm{XO}_{4}$ groups, the ionic conductivity can vary by up to a factor of 40 .

A poor fit to the ${ }^{23} \mathrm{Na}$ NMR spin-lattice relaxation times $\left(T_{1}\right)$ is obtained with a BPP model (3D diffusion), particularly in the HT regime (Figure 11). On the other hand, the
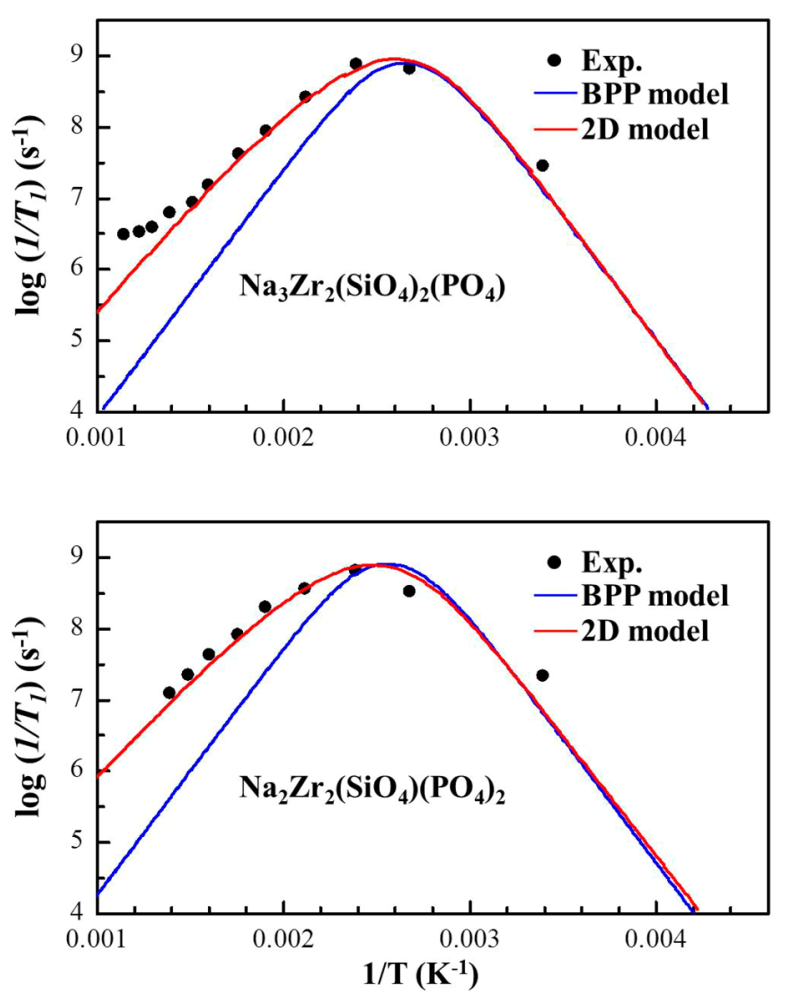

Figure 11. Inverse spin-lattice relaxation times of $\mathrm{Na}_{3} \mathrm{Zr}_{2}\left(\mathrm{SiO}_{4}\right)_{2}\left(\mathrm{PO}_{4}\right)$ (top) and $\mathrm{Na}_{2} \mathrm{Zr}_{2}\left(\mathrm{SiO}_{4}\right)\left(\mathrm{PO}_{4}\right)_{2}$ (bottom). Experimental (Exp.) data are shown with black points and the fit using the BPP and 2D diffusion model with blue and red lines, respectively.

application of a $2 \mathrm{D}$ diffusion model results in a very good agreement of NMR data and fit. This indicates that the nature of the $\mathrm{Na}^{+}$motion giving rise to the $T_{1}$ temperature dependence with a time scale of $10^{-8} \mathrm{~s}$ at approximately 416 $\mathrm{K}\left(T_{1}\right.$ minimum $\left.^{47}\right)$ is $2 \mathrm{D}$ on the local atomic scale of NMR although the long-range diffusion pathways are $3 \mathrm{D}$. This finding is in agreement with the rapid in-plane motion of $\mathrm{Na}^{+}$ions at the $\mathrm{Nal}$ sites, as revealed by the disc-shaped ADP (Figure 4). A detailed discussion of the dimensionality of $\mathrm{Na}^{+}$diffusion can be found in the Supporting Information.

The activation energies $\left(E_{\mathrm{a}}\right)$ have been derived from NMR, $\mathrm{AC}$ impedance, and $\mathrm{MD}$ simulations, which are summarized in Supporting Information Table S7 and Figure S8. All $E_{\mathrm{a}}$ values are between 0.2 and $0.5 \mathrm{eV}$, which are typical values for solid electrolyte materials. $^{6-8,36,75}$ In general, the results from all the techniques demonstrate the same trends across the composition range: higher activation energy values are obtained for larger $x$ (or $y$ ) values (lower $\mathrm{Si} / \mathrm{P}$ ratios). This agrees well with the trends in the ionic conductivity and confirms the good agreement between experiments and simulations. In the recent work of Samiee et al., DFT calculations confirmed that $\mathrm{Na}^{+}$motion activation barriers increase with a decrease in $\mathrm{Si} / \mathrm{P}$ ratio in the monoclinic NASICON structure. ${ }^{76}$

The diffusion coefficients $D^{T}$ obtained from NMR and the chemical diffusion coefficients $D_{c}$ calculated from the MD simulations have similar trends and values as a function of composition. For all compositions, the diffusion coefficient has a value of the order of $10^{-8} \mathrm{~cm}^{2} / \mathrm{s}$ at $473 \mathrm{~K}$, as shown in Figure 12. The diffusion coefficient decreases with a higher concentration of $\mathrm{Sc}^{3+}$-substitution, showing the same trends with that of the ionic conductivity data.
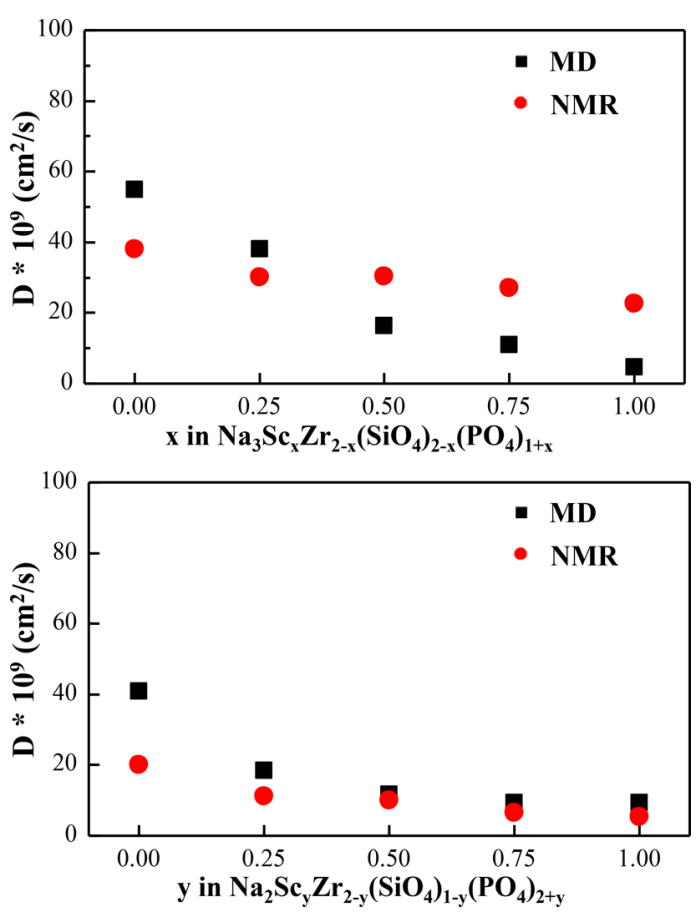

Figure 12. Diffusion coefficient $D^{T}$ obtained from NMR (red) and the chemical diffusion coefficient $D_{c}$ calculated from $\mathrm{MD}$ simulations (black) (at $473 \mathrm{~K}$ ).

3.3. $\mathrm{Na}^{+}$Ion Diffusion Mechanism. Diffusion Pathways. The $\mathrm{Na}^{+}$diffusion mechanism has been studied by both experimental and computational techniques to investigate the $\mathrm{Na}^{+}$diffusion pathways. ${ }^{10,21,61,74}$ In Figure 13, we plot the conduction pathways of $\mathrm{Na}^{+}$ions in $\mathrm{Na}_{3} \mathrm{Sc}_{0.25} \mathrm{Zr}_{1.75}\left(\mathrm{SiO}_{4}\right)_{1.75}$ $\left(\mathrm{PO}_{4}\right)_{1.25}$ using three different approaches: (i) MD density plots of the accumulated sodium ion trajectories over the simulated time scale, which reveal the migration pathways and the regions in the lattice that are most frequently traversed by the mobile $\mathrm{Na}^{+}$ions. (ii) Bond valence energy landscapes (BVEL) using the bond valence sum method, ${ }^{7,78}$ which has been applied to a range of ionic conductors. ${ }^{79,80}$ This method requires only the crystal structure as an input and can probe likely ion diffusion pathways with minimal computational cost, but lattice relaxation effects or cooperative mechanisms are not taken into account. (iii) The maximum-entropy method (MEM)/Rietveld analysis uses the scattering densities by giving the maximum variance of calculated structure factors within standard deviations of observed ones. In this way, structural information can be extracted effectively from the 


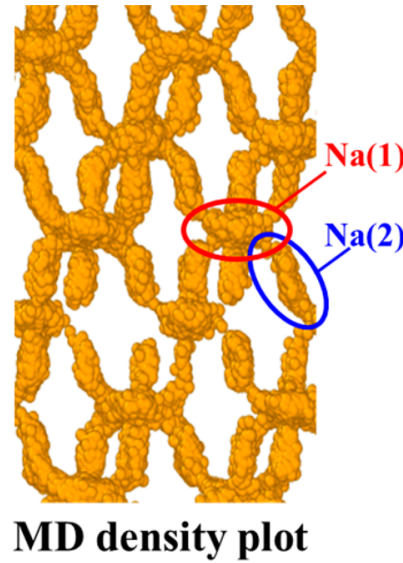

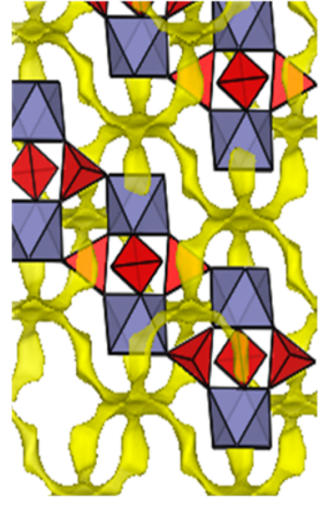

BVEL

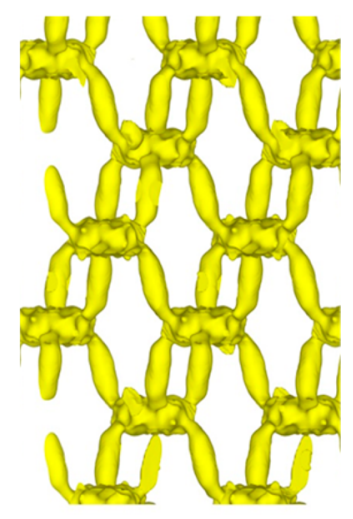

MEM/Rietveld

Figure 13. $\mathrm{Na}^{+}$ion diffusion pathways obtained from different techniques: (1) Left: MD density plot of $\mathrm{Na}^{+}$ions (473 K) accumulated for $1 \mathrm{~ns}$ with a step of 1 ps. (2) Center: BVEL methods with an iso-energy surface values of $1.0 \mathrm{eV}$. (3) Right: MEM/Rietveld method with an iso-surface level of $0.05 \mathrm{fm} \AA^{-3}$.

diffraction data and shown as three-dimensional distributions of scattering densities.

It is revealing that the diffusion pathways derived from the three techniques show very similar results and indicate a wellconnected 3D network (Figure 13). Such 3D diffusion behavior of sodium ions allows access to all possible pathways and helps to enhance the ionic conductivity. Furthermore, the $\mathrm{Na}^{+}$ density plot forms flat discs on the $\mathrm{Na}(1)$ sites and thin long ellipsoids on the $\mathrm{Na}(2)$ sites, which is exactly the same feature that is present in the Rietveld refined anisotropic atomic displacement parameters.

$\mathrm{Na}(1)-\mathrm{Na}$ (2) Site Exchange. As mentioned in Section 3.1, the rhombohedral NASICON form has two crystallographically different $\mathrm{Na}$ sites. The local $\mathrm{Na}-\mathrm{Na}$ environment is shown in Figure 14, where each $\mathrm{Na}(1)$ site is surrounded by six $\mathrm{Na}(2)$ sites and each $\mathrm{Na}(2)$ site is surrounded by two $\mathrm{Na}(1)$ sites. The approximate distances between different sites are indicated.

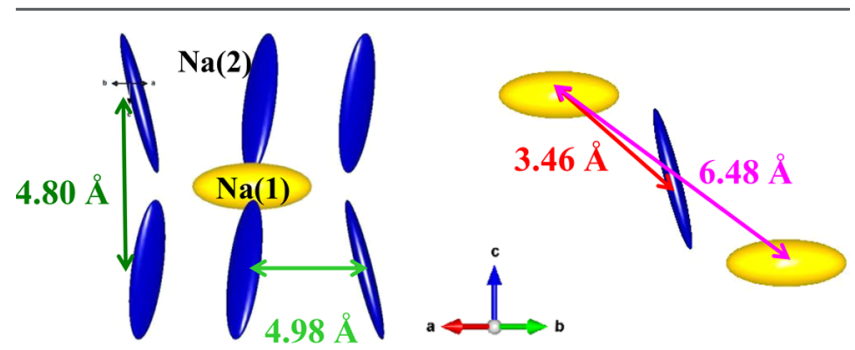

Figure 14. Two views of the local $\mathrm{Na}-\mathrm{Na}$ environment. $\mathrm{Na}(1)$ (yellow) and $\mathrm{Na}(2)$ (blue) sites are shown as displacement ellipsoids with a probability value of $95 \%$. The distances between Na site pairs are indicated.

Given that the $\mathrm{Na}(1)$ sites have a large separation $(6.48 \AA$ ) and the $\mathrm{Na}(2)$ sites are also far apart (4.98 $\AA$ ), it is reasonable to consider that most $\mathrm{Na}$ migration occurs between $\mathrm{Na}(1)$ and $\mathrm{Na}(2)$ sites where the distance is $3.46 \AA$. To verify such site exchange we re-examined the MD density plots. In Figure 13 the atomistic trajectory has been recorded separately for $\mathrm{Na}^{+}$ions according to their initial site: the density plots of $\mathrm{Na}^{+}$ions initially located at $\mathrm{Na}(1)$ and $\mathrm{Na}(2)$ sites at the beginning of the MD simulation are presented on the left and right of Figure 15 , respectively. As shown, when the two density plots are overlaid on top of each other, they are very similar and form well connected $3 \mathrm{D}$ pathways between the $\mathrm{Na}(1)$ and $\mathrm{Na}(2)$

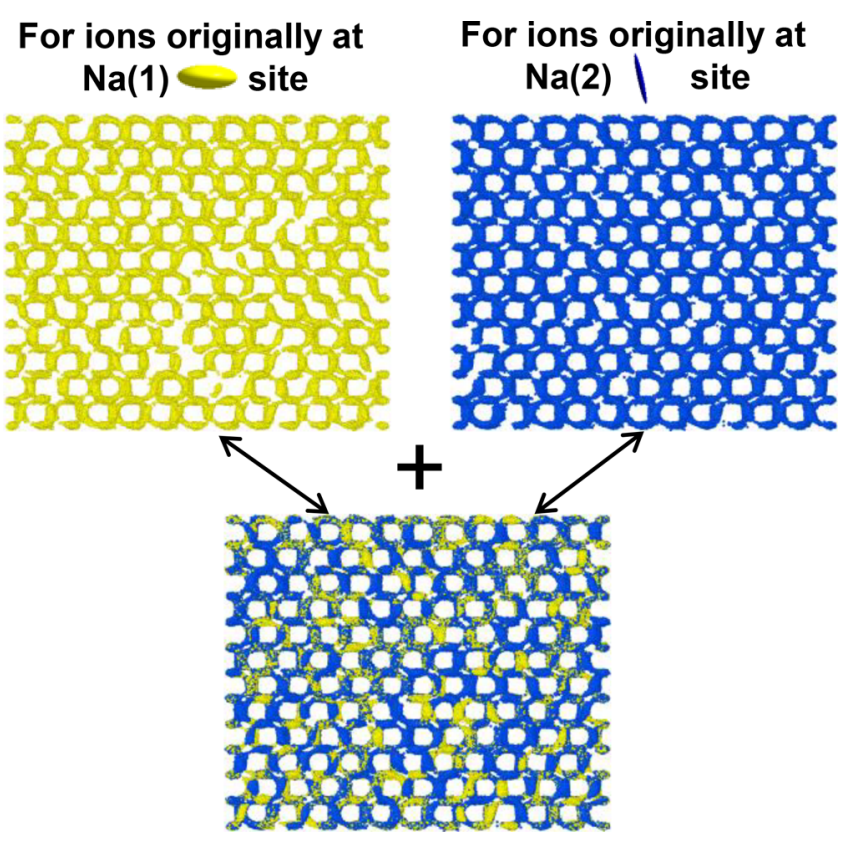

Figure 15. $\mathrm{Na}^{+}$-ion density from molecular dynamics simulation of $\mathrm{Na}_{3} \mathrm{Sc}_{0.25} \mathrm{Zr}_{1.75}\left(\mathrm{SiO}_{4}\right)_{1.75}\left(\mathrm{PO}_{4}\right)_{1.25}$ at $473 \mathrm{~K}$ for $\mathrm{Na}^{+}$ions initially on $\mathrm{Na}(1)$ sites (yellow, left) and $\mathrm{Na}(2)$ sites (blue, right). The lower figure overlays the upper figures.

sites. Furthermore, the zigzag pathways are in good agreement with the result reported by Kabbour et al. ${ }^{29}$ using probability density function calculations.

$\mathrm{Na}^{+}$-Ion Intersite Hopping. The typical time scales of sodium intersite hopping have not been extensively investigated previously for NASICON materials. To extract this information from the MD results we have calculated the van Hove correlation functions of which the transformed version of the self-part $r^{2} G_{s}(r, t)$ is related to the probability of an atom traveling a distance $r$ after a time interval of $t$. In Figure 16 we show an example of the $r^{2} G_{s}(r, t)$ of $\mathrm{Na}_{3} \mathrm{Sc}_{0.25} \mathrm{Zr}_{1.75}\left(\mathrm{SiO}_{4}\right)_{1.75^{-}}$ $\left(\mathrm{PO}_{4}\right)_{1.25}$ simulated at $773 \mathrm{~K}$.

Four main local maxima can be observed, from low to high $r$ values: (i) A first sharp and intense peak appears at $r=0.5 \AA$ which is related to local on-site vibrations of the $\mathrm{Na}^{+}$ions. A slight right shift of this peak is observed as the temperature of the simulation system increases, in line with the increased 


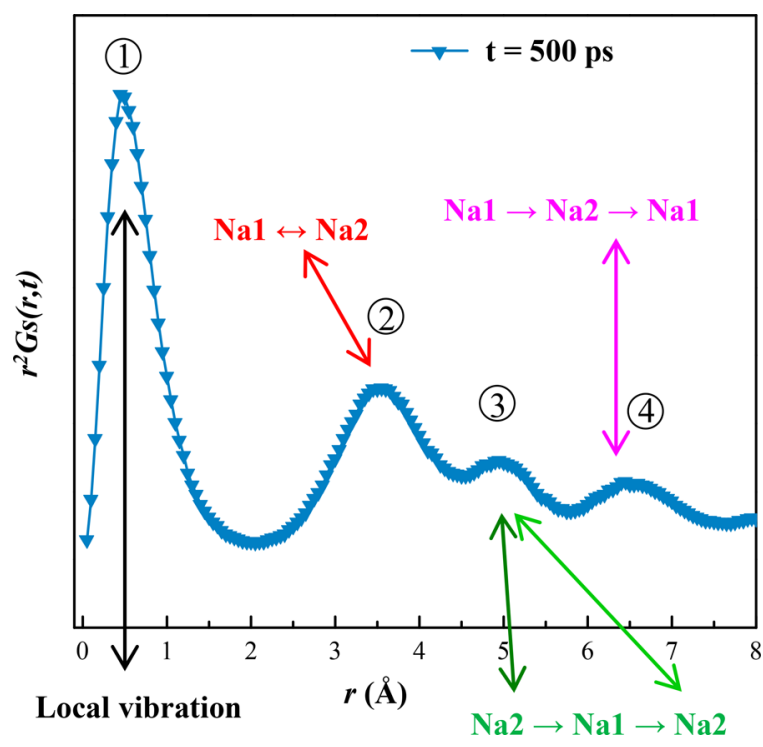

Figure 16. $\mathrm{Na}^{+}$-ion dynamics in $\mathrm{Na}_{3} \mathrm{Sc}_{0.25} \mathrm{Zr}_{1.75}\left(\mathrm{SiO}_{4}\right)_{1.75}\left(\mathrm{PO}_{4}\right)_{1.25}$ simulated at $773 \mathrm{~K}$ using a time scale of $500 \mathrm{ps}$. Vertical axis is the transformed self-part of the van Hove correlation function $r^{2} G_{s}(r, t)$ which is a measure of probability of moving a distance $r$. Different $\mathrm{Na}^{+}$ dynamical processes are indicated, and the colors of these correspond to the site exchange process indicated in Figure 14.

vibrational amplitudes as the kinetic energy of the $\mathrm{Na}^{+}$ions is raised. (ii) The second peak appearing at about $r=3.5 \AA$ corresponds to the distance between the $\mathrm{Na}(1)$ site and the $\mathrm{Na}(2)$ site as shown in Figure 14. This peak is indicative of hopping between neighboring $\mathrm{Na}(1)$ and $\mathrm{Na}(2)$ sites in accord with the NMR results. (iii) The third peak at about $r=5 \AA$ is the distance between two neighboring $\mathrm{Na}(2)$ sites. As there is an oxygen atom located directly between two $\mathrm{Na}(2)$ sites, direct migration of $\mathrm{Na}^{+}$between $\mathrm{Na}(2)$ sites is unfavorable. We observe instead that the $\mathrm{Na}^{+}$ion goes through a two-step process: starting from an $\mathrm{Na}(2)$ site, it moves to an $\mathrm{Na}(1)$ and then continues to another $\mathrm{Na}(2)$ site. (iv) The next peak at $r=$ $6.5 \AA$ is the distance between two $\mathrm{Na}(1)$ sites. Similar to the previous case, the peak can be considered as a two-step migration process following sites $\mathrm{Na}(1)-\mathrm{Na}(2)-\mathrm{Na}(1)$.

By plotting the self-part of the van Hove correlation functions with different time interval values (Figure 17) we can obtain insights into the time dependence of the $\mathrm{Na}^{+}$ion diffusion process. The van Hove correlation function starts to form a peak at $3.5 \AA$ in the first 10 ps, indicating that the site exchange between $\mathrm{Na}(1)$ and $\mathrm{Na}(2)$ sites can occur within a very short time scale. This peak has its highest intensity on time scales of $t=250 \mathrm{ps}$. As the time interval value increases, $\mathrm{Na}^{+}$ ions are able to accomplish the two-step migration process $(\mathrm{Na}(1) \rightarrow \mathrm{Na}(2) \rightarrow \mathrm{Na}(1)$ or $\mathrm{Na}(2) \rightarrow \mathrm{Na}(1) \rightarrow \mathrm{Na}(2))$, resulting in a decrease of intensity of the peak at $3.5 \AA$ but an increase of intensity of the peaks at 5 and $6.5 \AA$. The overall picture is of short-range hopping between $\mathrm{Na}(1)$ and $\mathrm{Na}(2)$ sites on a time scale of a few hundred picoseconds (where some of this is hopping back to the initial site) and long-range hopping on time scales of nanoseconds.

\section{CONCLUSIONS}

The NASICON-type $\mathrm{Na}_{3} \mathrm{Sc}_{x} \mathrm{Zr}_{2-x}\left(\mathrm{SiO}_{4}\right)_{2-x}\left(\mathrm{PO}_{4}\right)_{1+x}$ and $\mathrm{Na}_{2} \mathrm{Sc}_{y} \mathrm{Zr}_{2-y}\left(\mathrm{SiO}_{4}\right)_{1-y}\left(\mathrm{PO}_{4}\right)_{2+y}$ solid electrolytes have been investigated through a powerful multitechnique approach to

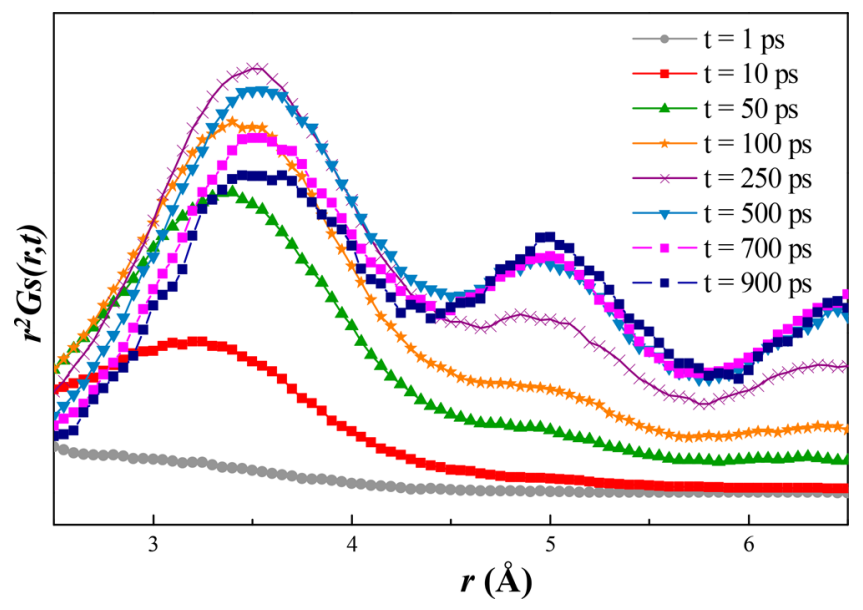

Figure 17. $\mathrm{Na}^{+}$-ion dynamics in $\mathrm{Na}_{3} \mathrm{Sc}_{0.25} \mathrm{Zr}_{1.75}\left(\mathrm{SiO}_{4}\right)_{1.75}\left(\mathrm{PO}_{4}\right)_{1.25}$ simulated at $773 \mathrm{~K}$ on different time scales. Vertical axis is the transformed self-part of the van Hove correlation function $r^{2} G_{s}(r, t)$ which is a measure of the probability of moving a distance $r$.

obtain detailed information on the crystal structures, local atomic environments, and $\mathrm{Na}^{+}$ion diffusion mechanisms.

First, the bulk crystal and local structures of these compositions have been determined using a combination of diffraction and solid-state NMR techniques. A phase transition between 295 and $473 \mathrm{~K}$ from monoclinic $\mathrm{C} 2 / \mathrm{c}$ to rhombohedral $R \overline{3} c$ is observed for the $\mathrm{Na}_{3} \mathrm{Sc}_{x} \mathrm{Zr}_{2-x}\left(\mathrm{SiO}_{4}\right)_{2-x^{-}}$ $\left(\mathrm{PO}_{4}\right)_{1+x}$ compositions, while $\mathrm{Na}_{2} \mathrm{Sc}_{y} \mathrm{Zr}_{2-y}\left(\mathrm{SiO}_{4}\right)_{1-y}\left(\mathrm{PO}_{4}\right)_{2+y}$ materials crystallize in a rhombohedral $R \overline{3} c$ unit cell in the same temperature range. Second, both AC impedance measurements and molecular dynamics (MD) simulations show ionic conductivity values of $10^{-5} \mathrm{~S} / \mathrm{cm}$ at $298 \mathrm{~K}$ and $10^{-3}$ $\mathrm{S} / \mathrm{cm}$ at $473 \mathrm{~K}$ for these $\mathrm{Sc}^{3+}$-substituted NASICON materials. Finally, the 3D diffusion pathways of sodium ions in the NASICON structure have been revealed, for the first time, by three different approaches: $\mathrm{MD}$, bond valence, and maximum entropy methods. ${ }^{23} \mathrm{Na}$ NMR measurements reveal that the 3D diffusion pathway consists of several 2D local hops between $\mathrm{Na}(1)$ and $\mathrm{Na}(2)$ sites. A key feature is that ion diffusion proceeds by site exchange between $\mathrm{Na}(1)$ and $\mathrm{Na}(2)$ sites with long-range diffusion occurring on time scales of less than a nanosecond (at $773 \mathrm{~K}$ ).

This systematic study provides important insights into the wider family of NASICON-type materials and will be valuable in identifying next-generation solid electrolytes.

\section{ASSOCIATED CONTENT}

\section{Supporting Information}

The Supporting Information is available free of charge on the ACS Publications website at DOI: 10.1021/acs.chemmater.7b05237.

Unit cell parameters, GoF, Rwp, Rp, and ADPs values of the Rietveld refinements; ${ }^{29} \mathrm{Si}$ NMR signals from measurements and DFT calculations; MSD plots, diffusion coefficient, ionic conductivity, and activation energy values from MD simulations; models used for NMR; and discussion of the dimensionality of the $\mathrm{Na}^{+}$ diffusion (PDF) 


\section{AUTHOR INFORMATION}

\section{Corresponding Authors}

*(C.M.) E-mail: christian.masquelier@u-picardie.fr.

*(M.S.I.) E-mail: m.s.islam@bath.ac.uk.

\section{ORCID}

Christopher Eames: 0000-0002-5548-2655

Kent J. Griffith: 0000-0002-8096-906X

Jean-Noël Chotard: 0000-0002-9867-7954

Clare P. Grey: 0000-0001-5572-192X

M. Saiful Islam: 0000-0003-3882-0285

Christian Masquelier: 0000-0001-7289-1015

\section{Author Contributions}

The manuscript was written through contributions of all authors. All authors have given approval to the final version of the manuscript and have contributed equally.

Notes

The authors declare no competing financial interest.

\section{ACKNOWLEDGMENTS}

The ALISTORE ERI and CNRS are acknowledged for supporting Y.D. through a joint $\mathrm{PhD}$ scholarship between Picardie (France) and Bath (U.K.). Y.D. thanks Dr. Thibault Broux for help in performing MEM calculations. Dr. Matthew T. Dunstan, Dr. Pieter C. M. M. Magusin, Dr. Javier CarreteroGonzález, Dr. Lauren E. Marbella, and Matthew J. Sullivan (all Cambridge, U.K.) are gratefully acknowledged for their help with NMR experiments and fruitful discussions. L.H.B.N. thanks the ERASMUS Mundus project for financial support. K.J.G. gratefully acknowledges funding from the Winston Churchill Foundation of the United States and the Herchel Smith Scholarship. We are grateful for support from the EPSRC for the Energy Materials Programme grant (EP/K016288/1) and Archer HPC facilities through the Materials Chemistry Consortium (EP/L000202/1). DFT calculations were performed on the Darwin Supercomputer of the University of Cambridge High Performance Computing Service (http:// www.hpc.cam.ac.uk/), provided by Dell Inc. using Strategic Research Infrastructure Funding from the Higher Education Funding Council for England and funding from the Science and Technology Facilities Council (U.K.). The Argonne National Laboratory is acknowledged for the SXRD measurements (11BM mail-in rapid access proposal: 47443).

\section{REFERENCES}

(1) Armand, M.; Tarascon, J.-M. Building Better Batteries. Nature 2008, 451 (7179), 652-657.

(2) Larcher, D.; Tarascon, J.-M. Towards Greener and More Sustainable Batteries for Electrical Energy Storage. Nat. Chem. 2015, 7, 19-29.

(3) Hueso, K. B.; Armand, M.; Rojo, T. High Temperature Sodium Batteries: Status, Challenges and Future Trends. Energy Environ. Sci. 2013, 6, 734-749.

(4) Ponrouch, A.; Dedryvère, R.; Monti, D.; Demet, A. E.; Ateba Mba, J. M.; Croguennec, L.; Masquelier, C.; Johansson, P.; Palacín, M. R. Towards High Energy Density Sodium Ion Batteries Through Electrolyte Optimization. Energy Environ. Sci. 2013, 6, 2361-2369.

(5) Kundu, D.; Talaie, E.; Duffort, V.; Nazar, L. F. The Emerging Chemistry of Sodium Ion Batteries for Electrochemical Energy Storage. Angew. Chem., Int. Ed. 2015, 54, 3431-3448.

(6) Li, J.; Ma, C.; Chi, M.; Liang, C.; Dudney, N. J. Solid Electrolyte: the Key for High-Voltage Lithium Batteries. Adv. Energy Mater. 2015, 5, 1401408 .
(7) Richards, W. D.; Tsujimura, T.; Miara, L. J.; Wang, Y.; Kim, J. C.; Ong, S. P.; Uechi, I.; Suzuki, N.; Ceder, G. Design and Synthesis of the Superionic Conductor $\mathrm{Na}_{10} \mathrm{SnP}_{2} \mathrm{~S}_{12}$. Nat. Commun. 2016, 7, 11009.

(8) Wang, Y.; Richards, W. D.; Ong, S. P.; Miara, L. J.; Kim, J. C.; Mo, Y.; Ceder, G. Design Principles for Solid-State Lithium Superionic Conductors. Nat. Mater. 2015, 14, 1026-1031.

(9) Hong, H. Y.-P. Crystal Structures and Crystal Chemistry in the System $\mathrm{Na}_{1+\mathrm{x}} \mathrm{Zr}_{2} \mathrm{Si}_{\mathrm{x}} \mathrm{P}_{3-\mathrm{x}} \mathrm{O}_{12}$. Mater. Res. Bull. 1976, 11, 173-182.

(10) Goodenough, J. B.; Hong, H. Y.-P.; Kafalas, J. A. Fast $\mathrm{Na}^{+}$-Ion Transport in Skeleton Structures. Mater. Res. Bull. 1976, 11, 203-220.

(11) de la Rochère, M.; d'Yvoire, F.; Collin, G.; Comès, R.; Boilot, J. P. NASICON Type Materials - $\mathrm{Na}_{3} \mathrm{M}_{2}\left(\mathrm{PO}_{4}\right)_{3}(\mathrm{M}=\mathrm{Sc}, \mathrm{Cr}, \mathrm{Fe}): \mathrm{Na}^{+}-$ $\mathrm{Na}^{+}$Correlations and Phase Transitions. Solid State Ionics 1983, 9, $825-828$.

(12) Chotard, J.-N.; Rousse, G.; David, R.; Mentré, O.; Courty, M.; Masquelier, C. Discovery of a Sodium-Ordered Form of $\mathrm{Na}_{3} \mathrm{~V}_{2}\left(\mathrm{PO}_{4}\right)_{3}$ below Ambient Temperature. Chem. Mater. 2015, 27, 5982-5987.

(13) Bui, K. M.; Dinh, V. A.; Okada, S.; Ohno, T. Hybrid Functional Study of the NASICON-Type $\mathrm{Na}_{3} \mathrm{~V}_{2}\left(\mathrm{PO}_{4}\right)_{3}$ : Crystal and Electronic Structures, and Polaron-Na Vacancy Complex Diffusion. Phys. Chem. Chem. Phys. 2016, 18 (39), 27226-27231.

(14) Park, H.; Jung, K.; Nezafati, M.; Kim, C.-S.; Kang, B. Sodium Ion Diffusion in Nasicon $\left(\mathrm{Na}_{3} \mathrm{Zr}_{2} \mathrm{Si}_{2} \mathrm{PO}_{12}\right)$ Solid Electrolytes: Effects of Excess Sodium. ACS Appl. Mater. Interfaces 2016, 8, 27814-27824.

(15) Guin, M.; Tietz, F.; Guillon, O. New Promising NASICON Material as Solid Electrolyte for Sodium-Ion Batteries: Correlation Between Composition, Crystal Structure and Ionic Conductivity of $\mathrm{Na}_{3+\mathrm{x}} \mathrm{Sc}_{2} \mathrm{Si}_{\mathrm{x}} \mathrm{P}_{3-\mathrm{x}} \mathrm{O}_{12}$. Solid State Ionics 2016, 293, 18-26.

(16) Ihlefeld, J. F.; Gurniak, E.; Jones, B. H.; Wheeler, D. R.; Rodriguez, M. A.; McDaniel, A. H. Scaling Effects in Sodium Zirconium Silicate Phosphate $\left(\mathrm{Na}_{1+\mathrm{x}} \mathrm{Zr}_{2} \mathrm{Si}_{\mathrm{x}} \mathrm{P}_{3-\mathrm{x}} \mathrm{O}_{12}\right)$ Ion-Conducting Thin Films. J. Am. Ceram. Soc. 2016, 99, 2729-2736.

(17) Kim, J.-K.; Lim, Y. J.; Kim, H.; Cho, G.-B.; Kim, Y. A Hybrid Solid Electrolyte for Flexible Solid-State Sodium Batteries. Energy Environ. Sci. 2015, 8, 3589-3596.

(18) Boilot, J. P.; Salanié, J. P.; Desplanches, G.; Le Potier, D. Phase Transformation in $\mathrm{Na}_{1+\mathrm{x}} \mathrm{Si}_{\mathrm{x}} \mathrm{Zr}_{2} \mathrm{P}_{3-\mathrm{x}} \mathrm{O}_{12}$ Compounds. Mater. Res. Bull. 1979, 14, 1469-1477.

(19) Qui, D. T.; Capponi, J. J.; Joubert, J. C.; Shannon, R. D. Crystal Structure and Ionic Conductivity in $\mathrm{Na}_{4} \mathrm{Zr}_{2} \mathrm{Si}_{3} \mathrm{O}_{12}$. J. Solid State Chem. 1981, 39, 219-229.

(20) Boilot, J. P.; Collin, G.; Colomban, P. Crystal Structure of the True NASICON: $\mathrm{Na}_{3} \mathrm{Zr}_{2} \mathrm{Si}_{2} \mathrm{PO}_{12}$. Mater. Res. Bull. 1987, 22, 669-676.

(21) Boilot, J. P.; Collin, G.; Colomban, P. Relation Structure-Fast Ion Conduction in the NASICON Solid Solution. J. Solid State Chem. 1988, 73, 160-171.

(22) Boilot, J. P.; Salanié, J. P.; Desplanches, G.; Le Potier, D. Phase Transformation in $\mathrm{Na}_{1+\mathrm{x}} \mathrm{Si}_{\mathrm{x}} \mathrm{Zr}_{2} \mathrm{P}_{3-\mathrm{x}} \mathrm{O}_{12}$ Compounds. Mater. Res. Bull. 1979, 14, 1469-1477.

(23) Jolley, A. G.; Taylor, D. D.; Schreiber, N. J.; Wachsman, E. D. Structural Investigation of Monoclinic-Rhombohedral Phase Transition in $\mathrm{Na}_{3} \mathrm{Zr}_{2} \mathrm{Si}_{2} \mathrm{PO}_{12}$ and Doped NASICON. J. Am. Ceram. Soc. 2015, 98, 2902-2907.

(24) Collin, G.; Comes, R.; Boilot, J. P.; Colomban, P. Disorder of Tetrahedra in NASICON-Type Structure-I. $\mathrm{Na}_{3} \mathrm{Sc}_{2}\left(\mathrm{PO}_{4}\right)_{3}$ : Structures and Ion-Ion Correlations. J. Phys. Chem. Solids 1986, 47, 843-854.

(25) Boilot, J. P.; Collin, G.; Comes, R. Stoichiometry and Phase Transitions in NASICON Type Compounds. Solid State Ionics 1983, 9, 829-833.

(26) Collin, G.; Comes, R.; Boilot, J.-P.; Colomban, P. NASICON Analog $\mathrm{Na}_{3} \mathrm{Sc}_{2}\left(\mathrm{PO}_{4}\right)_{3}$ : Thermal Behaviour of the $\alpha, \beta$ and $\gamma$ Types, Structure, Correlations and Transitions. Solid State Ionics 1988, 28-30, 437-441.

(27) Collin, G.; Comes, R.; Boilot, J. P.; Colomban, P. Disorder of Tetrahedra in NASICON-Type Structure-I. $\mathrm{Na}_{3} \mathrm{Sc}_{2}\left(\mathrm{PO}_{4}\right)_{3}$ : Structures and Ion-Ion Correlations. J. Phys. Chem. Solids 1986, 47, 843-854.

(28) Delmas, C.; Cherkaoui, F.; Nadiri, A.; Hagenmuller, P. A Nasicon-Type Phase as Intercalation Electrode: $\mathrm{NaTi}_{2}\left(\mathrm{PO}_{4}\right)_{3}$. Mater. Res. Bull. 1987, 22, 631-639. 
(29) Kabbour, H.; Coillot, D.; Colmont, M.; Masquelier, C.; Mentré, O. $\alpha-\mathrm{Na}_{3} \mathrm{M}_{2}\left(\mathrm{PO}_{4}\right)_{3}(\mathrm{M}=\mathrm{Ti}, \mathrm{Fe})$ : Absolute Cationic Ordering in NASICON-Type Phases. J. Am. Chem. Soc. 2011, 133, 11900-11903.

(30) von Alpen, U.; Bell, M. F.; Wichelhaus, W. Phase Transition in NASICON $\left(\mathrm{Na}_{3} \mathrm{Zr}_{2} \mathrm{Si}_{2} \mathrm{PO}_{12}\right)$. Mater. Res. Bull. 1979, 14, 1317-1322.

(31) Guin, M.; Tietz, F. Survey of the Transport Properties of Sodium Superionic Conductor Materials for use in Sodium Batteries. J. Power Sources 2015, 273, 1056-1064.

(32) Anantharamulu, N.; Rao, K. K.; Rambabu, G.; Kumar, B. V.; Radha, V.; Vithal, M. A Wide-Ranging Review on Nasicon Type Materials. J. Mater. Sci. 2011, 46, 2821-2837.

(33) Lalère, F.; Leriche, J. B.; Courty, M.; Boulineau, S.; Viallet, V.; Masquelier, C.; Seznec, V. An All-Solid State NASICON Sodium Battery Operating at $200{ }^{\circ} \mathrm{C}$. J. Power Sources 2014, 247, 975-980.

(34) Noguchi, Y.; Kobayashi, E.; Plashnitsa, L. S.; Okada, S.; Yamaki, J. Fabrication and Performances of All Solid-State Symmetric Sodium Battery Based on NASICON-Related Compounds. Electrochim. Acta 2013, 101, 59-65.

(35) Sorokin, N. I. $\mathrm{Na}^{+}$-Ion Conductivity of Double Phosphate $\mathrm{Na}_{3} \mathrm{Sc}_{2}\left(\mathrm{PO}_{4}\right)_{3}$ in the Region of the $\beta-\gamma$ Transition. Phys. Solid State 2014, 56, 678-681.

(36) Ma, Q.; Guin, M.; Naqash, S.; Tsai, C.-L.; Tietz, F.; Guillon, O. Scandium-Substituted $\mathrm{Na}_{3} \mathrm{Zr}_{2}\left(\mathrm{SiO}_{4}\right)_{2}\left(\mathrm{PO}_{4}\right)$ Prepared by a SolutionAssisted Solid-State Reaction Method as Sodium-Ion Conductors. Chem. Mater. 2016, 28, 4821-4828.

(37) Susman, S.; Delbecq, C. J.; Brun, T. O.; Prince, E. Fast Ion Transport in the NASICON Analog $\mathrm{Na}_{3} \mathrm{Sc}_{2}\left(\mathrm{PO}_{4}\right)_{3}$ : Structure and Conductivity. Solid State Ionics 1983, 9, 839-844.

(38) Subramanian, M. A.; Rudolf, P. R.; Clearfield, A. The Preparation, Structure, and Conductivity of Scandium-Substituted NASICONs. J. Solid State Chem. 1985, 60, 172-181.

(39) Squattrito, P. J.; Rudolf, P. R.; Hinson, P. G.; Clearfield, A.; Volin, K.; Jorgensen, J. D. Sodium and Oxygen Disorder in a Scandium-Substituted Nasicon: A Time of Flight Neutron Powder Diffraction Study of $\mathrm{Na}_{2.5} \mathrm{Zr}_{1.8} \mathrm{Sc}_{0.2} \mathrm{Si}_{1.3} \mathrm{P}_{1.7} \mathrm{O}_{12}$. Solid State Ionics 1988, 31, 31-40.

(40) Winand, J. M.; Rulmont, A.; Tarte, P. Ionic Conductivity of the $\mathrm{Na}_{1+\mathrm{x}} \mathrm{M}_{\mathrm{x}}^{\mathrm{III}} \mathrm{Zr}_{2-\mathrm{x}}\left(\mathrm{PO}_{4}\right)_{3}$ Systems ( $\left.\mathrm{M}=\mathrm{Al}, \mathrm{Ga}, \mathrm{Cr}, \mathrm{Fe}, \mathrm{Sc}, \mathrm{In}, \mathrm{Y}, \mathrm{Yb}\right) . J$. Mater. Sci. 1990, 25, 4008-4013.

(41) Kaus, M.; Guin, M.; Yavuz, M.; Knapp, M.; Tietz, F.; Guillon, O.; Ehrenberg, H.; Indris, S. Fast $\mathrm{Na}^{+}$Ion Conduction in NASICONType $\mathrm{Na}_{3.4} \mathrm{Sc}_{2}\left(\mathrm{SiO}_{4}\right)_{0.4}\left(\mathrm{PO}_{4}\right)_{2.6}$ Observed by ${ }^{23} \mathrm{Na}$ NMR Relaxometry. J. Phys. Chem. C 2017, 121, 1449-1454.

(42) Rodríguez-Carvajal, J. Recent Advances in Magnetic Structure Determination by Neutron Powder Diffraction. Phys. B 1993, 192, $55-69$.

(43) Izumi, F.; Momma, K. Three-Dimensional Visualization in Powder Diffraction. Solid State Phenom. 2007, 130, 15-20.

(44) Harris, R. K.; Becker, E. D.; Cabral de Menezes, S. M.; Goodfellow, R.; Granger, P. NMR Nomenclature: Nuclear Spin Properties and Conventions for Chemical Shifts. Magn. Reson. Chem. 2002, 40, 489-505.

(45) Eichele, K.; Wasylishen, R. E. ${ }^{31}$ P NMR Study of Powder and Single-Crystal Samples of Ammonium Dihydrogen Phosphate: Effect of Homonuclear Dipolar Coupling. J. Phys. Chem. 1994, 98, 31083113.

(46) Singh, A. P.; Ghadwal, R. S.; Roesky, H. W.; Holstein, J. J.; Dittrich, B.; Demers, J.-P.; Chevelkov, V.; Lange, A. Lewis Base Mediated Dismutation of Trichlorosilane. Chem. Commun. 2012, 48, $7574-7576$.

(47) Heitjans, P.; Karger, J. Diffusion in Condensed Matter - Methods, Materials, Models; Springer-Verlag: Berlin, Heidelberg, 2005.

(48) Indris, S.; Heitjans, P.; Uecker, R.; Roling, B. Li Ion Dynamics in a $\mathrm{LiAlO}_{2}$ Single Crystal Studied by ${ }^{7} \mathrm{Li}$ NMR Spectroscopy and Conductivity Measurements. J. Phys. Chem. C 2012, 116, 1424314247.

(49) Deng, Y.; Eames, C.; Chotard, J.-N.; Lalère, F.; Seznec, V.; Emge, S.; Pecher, O.; Grey, C. P.; Masquelier, C.; Islam, M. S. Structural and Mechanistic Insights into Fast Lithium-Ion Conduction in $\mathrm{Li}_{4} \mathrm{SiO}_{4}-\mathrm{Li}_{3} \mathrm{PO}_{4}$ Solid Electrolytes. J. Am. Chem. Soc. 2015, 137, 9136-9145.

(50) Kuhn, A.; Duppel, V.; Lotsch, B. V. Tetragonal $\mathrm{Li}_{10} \mathrm{GeP}_{2} \mathrm{~S}_{12}$ and $\mathrm{Li}_{7} \mathrm{GePS}_{8}$ - Exploring the Li Ion Dynamics in LGPS Li Electrolytes. Energy Environ. Sci. 2013, 6, 3548-3552.

(51) Clark, S. J.; Segall, M. D.; Pickard, C. J.; Hasnip, P. J.; Probert, M. I. J.; Refson, K.; Payne, M. C. First Principles Methods Using CASTEP. Z. Kristallogr. - Cryst. Mater. 2005, 220, 567-570.

(52) Perdew, J. P.; Burke, K.; Ernzerhof, M. Generalized Gradient Approximation Made Simple. Phys. Rev. Lett. 1996, 77, 3865-3868.

(53) Yates, J. R.; Pickard, C. J.; Mauri, F. Calculation of NMR Chemical Shifts for Extended Systems Using Ultrasoft Pseudopotentials. Phys. Rev. B: Condens. Matter Mater. Phys. 2007, 76, 24401.

(54) Pickard, C. J.; Mauri, F. All-Electron Magnetic Response with Pseudopotentials: NMR Chemical Shifts. Phys. Rev. B: Condens. Matter Mater. Phys. 2001, 63, 245101.

(55) Monkhorst, H. J.; Pack, J. D. Special Points for Brillouin-Zone Integrations. Phys. Rev. B 1976, 13, 5188-5192.

(56) Middlemiss, D. S.; Blanc, F.; Pickard, C. J.; Grey, C. P. SolidState NMR Calculations for Metal Oxides and Gallates: Shielding and Quadrupolar Parameters for Perovskites and Related Phases. J. Magn. Reson. 2010, 204, 1-10.

(57) Diez-Gómez, V.; Arbi, K.; Sanz, J. Modeling Ti/Ge Distribution in $\mathrm{LiTi}_{2-\mathrm{x}} \mathrm{Ge}_{\mathrm{x}}\left(\mathrm{PO}_{4}\right)_{3}$ NASICON Series by ${ }^{31} \mathrm{P}$ MAS NMR and FirstPrinciples DFT Calculations. J. Am. Chem. Soc. 2016, 138, 9479-9486.

(58) Scherf, L. M.; Pecher, O.; Griffith, K. J.; Haarmann, F.; Grey, C. P.; Fässler, T. F. Zintl Phases $\mathrm{K}_{4-\mathrm{x}} \mathrm{Na}_{\mathrm{x}} \mathrm{Si}_{4}(1 \leq x \leq 2.2)$ and $\mathrm{K}_{7} \mathrm{NaSi}_{8}$ : Synthesis, Crystal Structures, and Solid-State NMR Spectroscopic Investigations. Eur. J. Inorg. Chem. 2016, 2016, 4674-4682.

(59) Islam, M. S.; Fisher, C. A. J. Lithium and Sodium Battery Cathode Materials: Computational Insights into Voltage, Diffusion and Nanostructural Properties. Chem. Soc. Rev. 2014, 43, 185-204.

(60) Adams, S.; Prasada Rao, R. Simulated Defect and Interface Engineering for High Power Li Electrode Materials. Solid State Ionics 2011, 184, 57-61.

(61) Roy, S.; Kumar, P. P. Influence of $\mathrm{Si} / \mathrm{P}$ Ordering on $\mathrm{Na}^{+}$ Transport in NASICONs. Phys. Chem. Chem. Phys. 2013, 15, 49654969.

(62) Armstrong, A. R.; Lyness, C.; Panchmatia, P. M.; Islam, M. S.; Bruce, P. G. The Lithium Intercalation Process in the Low-Voltage Lithium Battery Anode $\mathrm{Li}_{1+\mathrm{x}} \mathrm{V}_{1-\mathrm{x}} \mathrm{O}_{2}$. Nat. Mater. 2011, 10, 223-229.

(63) Billaud, J.; Eames, C.; Tapia-Ruiz, N.; Roberts, M. R.; Naylor, A. J.; Armstrong, A. R.; Islam, M. S.; Bruce, P. G. Evidence of Enhanced Ion Transport in Li-Rich Silicate Intercalation Materials. Adv. Energy Mater. 2017, 7, 1601043.

(64) Deng, Y.; Eames, C.; Fleutot, B.; David, R.; Chotard, J.-N.; Suard, E.; Masquelier, C.; Islam, M. S. Enhancing the Lithium Ion Conductivity in Lithium Superionic Conductor (LISICON) Solid Electrolytes through a Mixed Polyanion Effect. ACS Appl. Mater. Interfaces 2017, 9, 7050-7058.

(65) Pedone, A.; Malavasi, G.; Menziani, M. C.; Cormack, A. N.; Segre, U. A New Self-Consistent Empirical Interatomic Potential Model for Oxides, Silicates, and Silica-Based Glasses. J. Phys. Chem. B 2006, 110, 11780-11795.

(66) Plimpton, S. Fast Parallel Algorithms for Short-Range Molecular Dynamics. J. Comput. Phys. 1995, 117, 1-19.

(67) Zhu, Z.; Chu, I.-H.; Deng, Z.; Ong, S. P. Role of $\mathrm{Na}^{+}$Interstitials and Dopants in Enhancing the $\mathrm{Na}^{+}$Conductivity of the Cubic $\mathrm{Na}_{3} \mathrm{PS}_{4}$ Superionic Conductor. Chem. Mater. 2015, 27, 8318-8325.

(68) Van Hove, L. Correlations in Space and Time and Born Approximation Scattering in Systems of Interacting Particles. Phys. Rev. 1954, 95, 249-262.

(69) Tkachev, V. V.; Ponomarev, V. I.; Atovmyan, L. O. Crystal Structure of the Solid Electrolyte $\mathrm{Na}_{3} \mathrm{Sc}_{2}\left(\mathrm{PO}_{4}\right)_{3}$ in the Temperature Range $27-350{ }^{\circ} \mathrm{C}$. J. Struct. Chem. 1984, 25, 111-116.

(70) Pecher, O.; Carretero-González, J.; Griffith, K. J.; Grey, C. P. Materials' Methods: NMR in Battery Research. Chem. Mater. 2017, 29, 213-242. 
(71) Jäger, C.; Scheler, G.; Sternberg, U.; Barth, S.; Feltz, A. ${ }^{29}$ Si and ${ }^{31} \mathrm{P}$ MAS NMR Study of the NASICON System $\mathrm{Na}_{1+\mathrm{x}} \mathrm{Zr}_{2}\left(\mathrm{SiO}_{4}\right)_{\mathrm{x}}\left(\mathrm{PO}_{4}\right)_{3-\mathrm{x} .}$. Chem. Phys. Lett. 1988, 147, 49-52.

(72) Liu, Z.; Venkatachalam, S.; van Wüllen, L. Structure, Phase Separation and Li Dynamics in Sol-Gel-Derived $\mathrm{Li}_{1+\mathrm{x}} \mathrm{Al}_{\mathrm{x}} \mathrm{Ge}_{2-\mathrm{x}}\left(\mathrm{PO}_{4}\right)_{3}$. Solid State Ionics 2015, 276, 47-55.

(73) Irvine, J. T. S.; Sinclair, D. C.; West, A. R. Electroceramics: Characterization by Impedance Spectroscopy. Adv. Mater. 1990, 2, 132-138.

(74) Roy, S.; Kumar, P. P. Influence of Cationic Ordering on Ion Transport in NASICONs: Molecular Dynamics Study. Solid State Ionics 2013, 253, 217-222.

(75) Bachman, J. C.; Muy, S.; Grimaud, A.; Chang, H.-H.; Pour, N.; Lux, S. F.; Paschos, O.; Maglia, F.; Lupart, S.; Lamp, P.; Giordano, L.; Shao-Horn, Y. Inorganic Solid-State Electrolytes for Lithium Batteries: Mechanisms and Properties Governing Ion Conduction. Chem. Rev. 2016, 116, 140-162.

(76) Samiee, M.; Radhakrishnan, B.; Rice, Z.; Deng, Z.; Meng, Y. S.; Ong, S. P.; Luo, J. Divalent-Doped $\mathrm{Na}_{3} \mathrm{Zr}_{2} \mathrm{Si}_{2} \mathrm{PO}_{12}$ Natrium Superionic Conductor: Improving the Ionic Conductivity via Simultaneously Optimizing the Phase and Chemistry of the Primary and Secondary Phases. J. Power Sources 2017, 347, 229-237.

(77) Brown, I. D. Recent Developments in the Methods and Applications of the Bond Valence Model. Chem. Rev. 2009, 109, 6858-6919.

(78) Adams, S.; Rao, R. P. Transport Pathways for Mobile Ions in Disordered Solids from the Analysis of Energy-Scaled Bond-Valence Mismatch Landscapes. Phys. Chem. Chem. Phys. 2009, 11, 3210-3216.

(79) Wen, B.; Liu, J.; Chernova, N. A.; Wang, X.; Janssen, Y.; Omenya, F.; Khalifah, P. G.; Whittingham, M. S. $\mathrm{Li}_{3} \mathrm{Mo}_{4} \mathrm{P}_{5} \mathrm{O}_{24}$ : A Two-Electron Cathode for Lithium-Ion Batteries with Three-Dimensional Diffusion Pathways. Chem. Mater. 2016, 28, 2229-2235.

(80) Strauss, F.; Rousse, G.; Corte, D. A. D.; Hassine, M. B.; Saubanere, M.; Tang, M.; Vezin, H.; Courty, M.; Dominko, R.; Tarascon, J.-M. Electrochemical Activity and High Ionic Conductivity of Lithium Copper Pyroborate $\mathrm{Li}_{6} \mathrm{CuB}_{4} \mathrm{O}_{10}$. Phys. Chem. Chem. Phys. 2016, 18, 14960-14969. 